\title{
Alluvial sedimentation and tectono- stratigraphic evolution in a narrow extensional zigzag basin margin (northern Teruel Basin, Spain)
}

\author{
Lope Ezquerro*iD, Aránzazu Luzón, José L. Simón and Carlos L. Liesa
}

\begin{abstract}
The northern part of the eastern margin of the extensional Neogene Teruel Basin (central-eastern Spain) consists of a non-linear, zigzag fault zone made of alternating ca. $2 \mathrm{~km}$ long, NNW-SSE trending segments and shorter NNESSW ones. Good outcrop conditions made possible a comprehensive integrated stratigraphic and structural study, especially focused on coarse clastic sediments deposited along the basin margin. Well-exposed stratal relationships with boundary faults, allowed the analysis of tectonic influence on sedimentation. Synsedimentary deformation includes growth faulting, rollover anticlines, and monoclines and associated onlap stratal terminations, angular unconformities, and other complex growth strata geometries. One of them is the onlap-over-rollover bed arrangement described here for the first time, which reveals the competition between tectonic subsidence and sedimentary supply. Both, the structural inheritance (dense Mesozoic fracture grid) and the dominant, nearly 'multidirectional' ( $\sigma_{1}$ vertical, $\sigma_{2} \approx \sigma_{3}$ ), Pliocene extensional regime with $\sigma_{3}$ close to $\mathrm{E}-\mathrm{W}$, are considered to have controlled the margin structure and evolution. Tectono-stratigraphic evolution includes: (i) reactivation of inherited NNW-SSE faults and development of W-SW-directed small alluvial fans (SAF) while NNE-SSW segments acted as gentle relay ramp zones; (ii) progressive activation of NNE-SSW faults and development of NW-directed very small alluvial fans (VSAF); during stages $\mathrm{i}$ and ii sediments were trapped close to the margin, avoiding widespread progradation; (iii) linking of NNW-SSE and NNE-SSW structural segments, overall basin sinking and widespread alluvial progradation; (iv) fault activity attenuation and alluvial retrogradation. The particular structure and kinematic evolution of this margin controlled alluvial system patterns. Size of alluvial fans, directly set up at the border faults, was conditioned by the narrowness of the margin, small catchment areas, and proximity between faults, which prevented the development of large alluvial fans. The size of the relay zones, only a few hundred meters wide, acted in the same way, avoiding them to act as large sediment transfer areas and large alluvial fans to be established. These features make the Teruel Basin margin different to widely described extensional margins models.
\end{abstract}

Keywords: Extensional basin, Alluvial fan, Stratal stacking pattern, Structural inheritance, Fault linkage

\footnotetext{
* Correspondence: lopezquerro@gmail.com

Departamento de Ciencias de la Tierra, Facultad de Ciencias, Geotransfer

Research Group and Instituto de Investigación en Ciencias Ambientales

(IUCA), Universidad de Zaragoza, Pedro Cerbuna 12, 50009 Zaragoza, Spain
} 


\section{Introduction}

Increasing knowledge of tectono-sedimentary evolution of basin margins characterised by coalescent oblique fault sets that form a continuous zigzag has developed in the last two decades (e.g., Gupta et al. 1999; Gawthorpe and Leeder 2000; Younes and McClay 2001, 2002; Gawthorpe et al. 2003a, b; Pascucci et al. 2006; Moustafa and Khalil 2017a, b). In such geological contexts, inward fault kinks exert a strong influence on basin sedimentation, e.g., controlling the location of syntectonic clastic sediment entries (Moustafa and Khalil 2017a, b). Some works focus on the stratigraphy related to margins, both in oceanic (Gawthorpe et al. 1994, 1997; Dawers and Underhill 2000; Jackson et al. 2002, 2006b) and, less profusely, in continental basins (Leeder and Jackson 1993; Jackson and Leeder 1994; Moustafa and Khalil 2017a, b). Nevertheless, not enough is known about the relative role that distinct tectonic features (structural inheritance, propagation and linkage patterns, stress fields) exert on the development of zigzag margins and associated sedimentation. The sequential activity of faults in this type of basin borders (Gawthorpe et al. 2003a, b) requires complex evolutionary models in which all those tectonic controls should be taken into account.

Many numerical, analogue or natural models concerning the evolution of active extensional basin margins consider fault interaction and linkage as a key issue. Peacock and Sanderson $(1991,1994)$ describe how two non-interacting overstepping segments evolve to a single fault through relay ramp and breached ramp stages. Cartwright et al. (Cartwrigth et al. 1995) and Gawthorpe and Leeder (2000) relate those evolutionary stages to characteristic displacement-length profiles that express the degree and type of fault interaction prior to linkage. Some works focus on faulting geometries in linkage zones (Walsh et al. 1999), while others regard as important the role of stress perturbations near fault tips and their influence on length-displacement ratios and displacement gradients (Willemse et al. 1996; Crider and Pollard 1998; Gupta and Scholz 2000). Most of these models assume an undeformed rock massif in which new fault systems develop. This hypothesis is, however, not realistic due to common influence of inherited structures corresponding to previous deformational episodes (Trudgill and Cartwright 1994; Trudgill 2002). Although relationships between overall rifting processes and preexisting lithospheric weakness zones are usually undeniable, evincing the role of structural inheritance on the development of a given fault system becomes very complex (Corti et al. 2007; Rotevatn et al. 2018). Such a role has been proved by means of (i) serial cross-sections and 3D modelling, in e.g., Suez Gulf area (Moustafa 1997; Moustafa 2002), Vallès-Penedès Fault, Spain (Belenguer Oliver et al. 2012) and Malawi Rift (Mortimer et al.
2016), or (ii) analogue and numerical modelling (e.g., McClay et al. 2002; Hus et al. 2005; Corti et al. 2007).

The contribution of sequence stratigraphy methods to the study of extensional sedimentary basins is not in doubt (Gawthorpe et al. 1994). Sequence stratigraphy analyzes the sedimentary response to changes in base level, and the depositional trends that arise from accommodation space and sedimentation interplay (Catuneanu et al. 2011). Definition of genetic units (Posamentier and Vail 1988; Pardo et al. 1989) is based on megasequential trends (e.g., vertical variations of grain size or lithofacies), stratal stacking patterns and bounding surfaces, being such units limited by chronostratigraphically significant surfaces that mark changes in the whole basin stratigraphy. In continental tectonically active basins stratal geometry and stratigraphic trend (i.e. megasequences) are mainly controlled by tectonic subsidence/ uplift, sediment supply and basin physiography (Lambiase 1990; Gawthorpe et al. 1994; Contreras et al. 1997; Carroll and Bohacs 1999). Establishing megasequences in such contexts is crucial for deciphering the palaeogeographical evolution, including morphostructural configuration, location of sedimentation and erosion areas, and main points of sediment entry into the basin (Pardo et al. 1989; Gawthorpe and Hurst 1993; Leeder and Jackson 1993; Muñoz-Jiménez and Casas-Sainz 1997; Gawthorpe and Leeder 2000; Luzón 2005; Santolaria et al. 2015).

The purpose of this paper is to establish the tectonosedimentary Pliocene evolution of a narrow zigzag basin margin and to analyse the role of both the inherited fracture network and a spatially and temporally heterogeneous stress field in the selective reactivation and propagation of faults and on alluvial sedimentation. An integrated stratigraphic and structural study has been completed in the extensional active margin of the northern Teruel half-graben (NE Spain), and was focused on the stratigraphy of coarse clastic rocks developed along the basin margin and their stratal relationships with the boundary faults. This study has allowed us to propose a detailed model for the basin margin evolution and to discuss the main differences with proposed ones in lager basins.

\section{Geological setting}

The Neogene Teruel Basin is an elongated, NNE-SSW trending intra-mountain graben situated in the centraleastern Iberian Chain, eastern Spain (Fig. 1a). The structural evolution of this chain was primarily controlled by the late-Variscan (Carboniferous-Permian) wrench faulting (Álvaro et al. 1979). During Mesozoic rifting episodes in the whole study area, NW-SE and NE-SW fault reactivation and activation of new structures, gave rise to the Iberian Basin, which was compartmentalized, specially during the Early Cretaceous, into distinct sub-basins with 


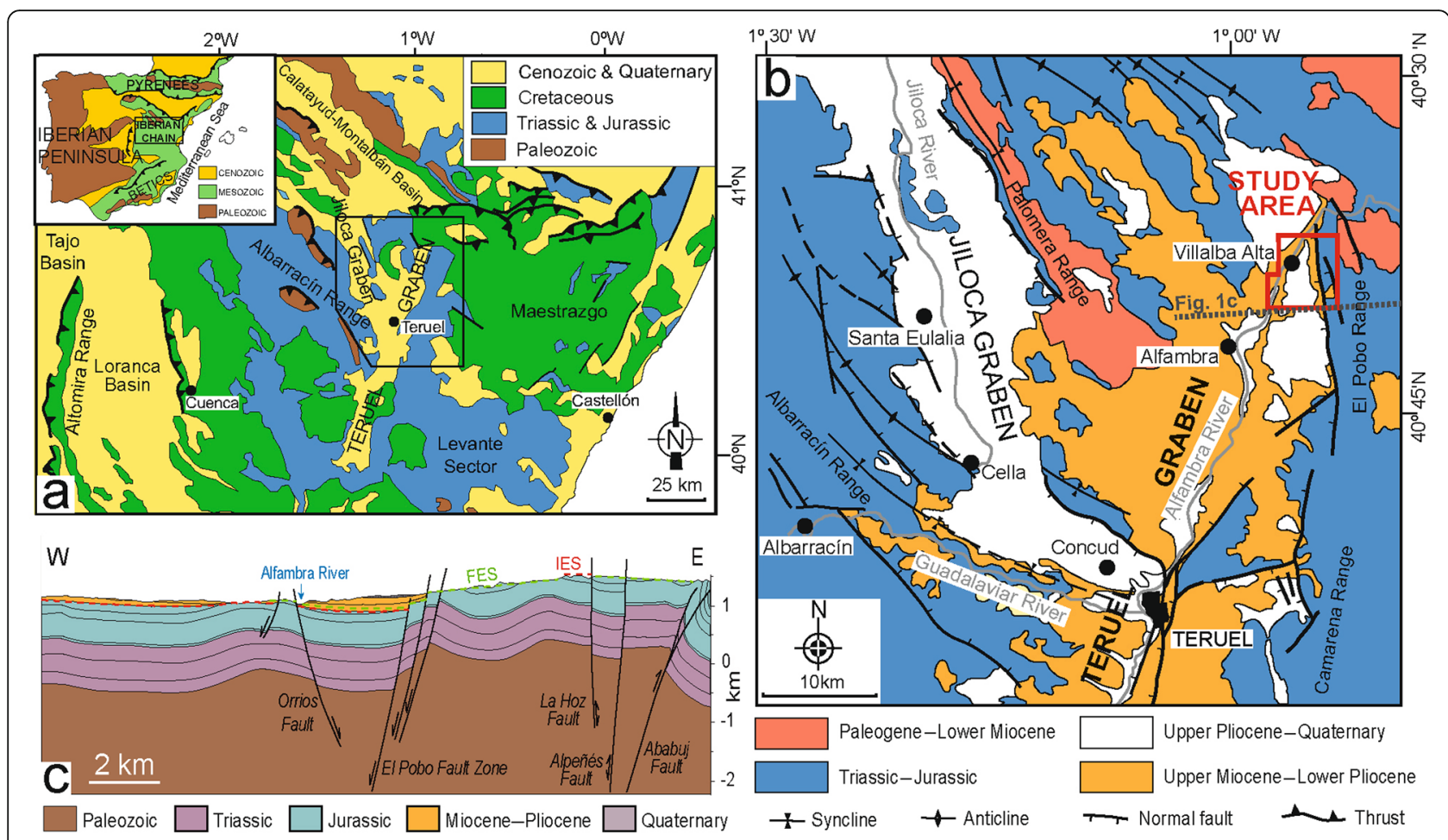

Fig. 1 a Location of the Teruel Basin in the eastern Iberian Peninsula; b Geological map of the northern sector of the Teruel Basin with location of the study area; c Geological cross-section showing the half-graben geometry of the northern Teruel Basin (see location in b)

differential subsidence (Álvaro et al. 1979; Salas and Casas 1993; Soria 1997; Soria et al. 2000; Capote et al. 2002; Liesa et al. 2019b). In early Cenozoic, during Europe-Africa convergence, Mesozoic basins were inverted to form the NWSE trending Iberian Chain (e.g., Guimerà and Álvaro 1990; Capote et al. 2002; Liesa et al. 2018). The region underwent compression along several directions, NE-SW, SE-NW, SSE-NNW and NNE-SSW (Liesa and Simón 2009).

Since the middle Miocene, extensional tectonics associated to the Valencia Trough (Mediterranean Sea) affected the central-eastern part of the chain (Álvaro et al. 1979; Simón 1982; Capote et al. 2002). During this time, the stress field evolved from a nearly $\mathrm{N}-\mathrm{S}$ oriented compression to (i) a triaxial extension with minimum stress $\left(\sigma_{3}\right)$ trajectories oriented WNW-ESE, prevailing during Late Miocene, and to (ii) a biaxial, near 'multidirectional' tension $\left(\sigma_{1}\right.$ vertical, $\left.\sigma_{2} \approx \sigma_{3}\right)$ with $\sigma_{3}$ trending nearly WSW-ENE, prevailing since Pliocene (Simón 1982, 1986, 1989; Herraiz et al. 2000; Liesa 2000, 2011a; Capote et al. 2002; Arlegui et al. 2005, 2006; Liesa and Simón 2009; Liesa et al. 2019a). This resulted in reactivation of Alpine compressional (early Cenozoic) and Mesozoic extensional structures and initiation of new normal faults. As a result, the Iberian Chain was obliquely cut by a number of extensional basins, as the NNE-SSW trending Teruel and Maestrat grabens and the NNW-SSE trending Jiloca Graben (Fig. 1a).
The Neogene Teruel basin fill, under $500 \mathrm{~m}$ in thickness, consists of detrital, carbonate and gypsum deposits from alluvial fans and shallow lakes (Weerd 1976; Moissenet 1980; Godoy et al. 1983; Ezquerro et al. 2012a; Ezquerro 2017). In general, coarse terrigenous facies appear close to basin margins in tectonic contact with or onlapping Mesozoic or Oligocene rocks, and correspond to proximal alluvial areas. They grade basinwards to medium and fine grain-sized detrital facies, which correspond to middle and distal alluvial sectors with, locally, interdigitated calcretes. Alluvial fan radius ranges from 1 to $12 \mathrm{~km}$ in length, the shorter ones are those sourced in the eastern, active margin (Ezquerro 2017). The distal alluvial facies are laterally related to carbonates and gypsum associated to shallow lacustrine environments that covered wide areas in the central zones of the basin.

Tectonics has been recently proposed as the main control on sedimentary evolution (Ezquerro et al. 2014; Ezquerro 2017; Liesa et al. 2019a), founded on conspicuous angular unconformities and other pieces of evidence of active tectonism (e.g., growth-strata and seismites). Based on mammal sites (Alcalá et al. 2000), as well as on magnetostratigraphical constraints (Opdyke et al. 1997; Ezquerro et al. 2012b, 2016), the age of the sedimentary infill in the northern Teruel Basin has been bracketed by Ezquerro (2017) between the earliest Vallesian (middle 
Miocene, ca. 11.2 Ma) and the latest Villafranchian (Late Pliocene-Early Pleistocene, 1.8 Ma).

The study area is located in the northernmost sector of the basin (Fig. 1b), where the basin shows a halfgraben structure, with the eastern active boundary controlled by the N-S striking El Pobo extensional fault zone (Simón 1983; Moissenet 1983; Liesa 2011a, b; Rodríguez-López et al. 2012; Liesa et al. 2016) (Fig. 1c). During Neogene times, the basin evolved in parallel with two extensive planation surfaces developed on the upthrown blocks (as the El Pobo Range): (i) the Intramiocene Erosion Surface (IES) (Gutiérrez and Peña 1976; Peña et al. 1984; S1 of Gutiérrez and Gracia 1997), and (ii) the Fundamental Erosion Surface (FES) (Peña et al. 1984; S2 + S3 of Gutiérrez and Gracia 1997). Based on their correlative stratigraphic units, these planation surfaces have been dated to $\sim 11.2 \mathrm{Ma}$ (Middle Miocene) and $\sim 3.5 \mathrm{Ma}$ (Late Pliocene), respectively (Ezquerro 2017). They represent critical milestones in the Teruel Basin evolution, since they roughly correlate, respectively, with the beginning and the end of the basin endorheic sedimentation (Simón 1982, 1983).

Tectonic deformation of the FES since middle Pliocene times, perhaps combined with far-field base level fall, coincided with strong modification of the basin pattern (Liesa et al. 2019a). Sedimentation ceased in most of the basin, the FES planation surface being topographically connected to the top of lower Pliocene lacustrine rocks. Nevertheless, at the northernmost sector (Orrios-Escorihuela area), the downthrown block of the El Pobo Fault Zone continued as an endorheic domain.

\section{Methods}

A combined stratigraphic and tectonic analysis was carried out to establish the tectono-sedimentary characteristics of the infill. The stratigraphic study consisted of detailed logging and correlation of nine stratigraphical profiles along the studied margin and field observations as a basis for the division of the sedimentary record into several mappable lithofacies associations. Each association was defined by its lithology, bed shapes, textural features and sedimentary structures, and represents a different sedimentary subenvironment. The stratigraphic trend was analysed for each profile, and several megasequences established based on lithofacies or grain-size vertical changes. Dating of the succession has been carried out from data of several mammal localities (Mein et al. 1990) and two magnetostratigraphic profiles (Opdyke et al. 1997).

The tectonic study was based on identification and mapping of faults and other associated deformation structures during field survey and using orthorectified satellite imagery (1:5000 scale), in order to reconstruct the geometry of the basin margin. Also, fractures at outcrop scale were measured and analysed, and paleostress analysis was carried out in three sites where adequate fault samples were collected. Two samples including fault slickenlines were analysed by applying Etchecopar's (Etchecopar et al. 1981), Right Dihedra (Pegoraro 1972) and $y$-R diagram (Simón 1982, 1986) methods. The third one provided meso-scale fault planes showing small offsets but no visible striation; consequently, it was analysed by the method proposed by Lisle et al. (2001). Additionally, the compilation of paleostress results all over the northern Teruel Basin, recently achieved by Ezquerro (2017) and Liesa et al. (2019a) was taken into account in order to understand the overall evolution of recent stress fields.

Intensive outcrop-scale field study along the active basin margin revealed different styles of geometrical relationships between stratigraphic units and border faults. The tectono-sedimentary study in selected outcrops has permitted to infer the deformation kinematics, to identify stratigraphical megasequences, to analyse the relationship between accommodation space and sedimentation, and to propose an evolutionary model for the basin margin. Special attention was paid to fault interaction and linkage processes within the framework of the recent tectonic stress field.

\section{Results}

\subsection{The Pliocene sedimentary succession}

\subsubsection{Lithofacies associations and sedimentary systems}

The nine stratigraphic profiles studied in the northern Teruel Basin have been correlated and thereafter projected into two W-E sections, corresponding to the northern (Villalba Alta) and southern (Orrios) sectors of the study area, respectively (Figs. 2 and 3). Detrital deposits crop out in the eastern part of the studied area (e.g., profiles 4, 5, and 6), while carbonates increase westwards (profiles 7 and 8); in any case, in some profiles (e.g., 1 and 8) both kinds of deposits are present (Fig. 3). Five mappable lithofacies associations, representing sedimentation in a specific sedimentary subenvironment, have been distinguished: Conglomerate $(\mathrm{C})$, Conglomerate and sandstone (CS), Conglomerate and mudstone (CM), Mudstone (M), and Limestone and marl (LM). The main features of each lithofacies association (lithology and texture, stratal geometry, sedimentary structures) as well as the inferred sedimentary processes and subenvironments are summarised in Table 1 and Fig. 4.

Lithofacies $\mathrm{C}$ represents deposition in proximal alluvial fan areas (Table 1, Fig. 4). Depending on the textural features of these deposits, flash floods (clast-supported facies) or sediment gravity flow processes (matrix-supported facies), mainly debris flows (Lowe 1982; Dasgupta 2003), have been interpreted. Water flows from feeder channels lost their confinement after reaching the basin and resulted in high-energy flash floods that rapidly decrease in energy and transport capacity (Postma and Roep 1985; 


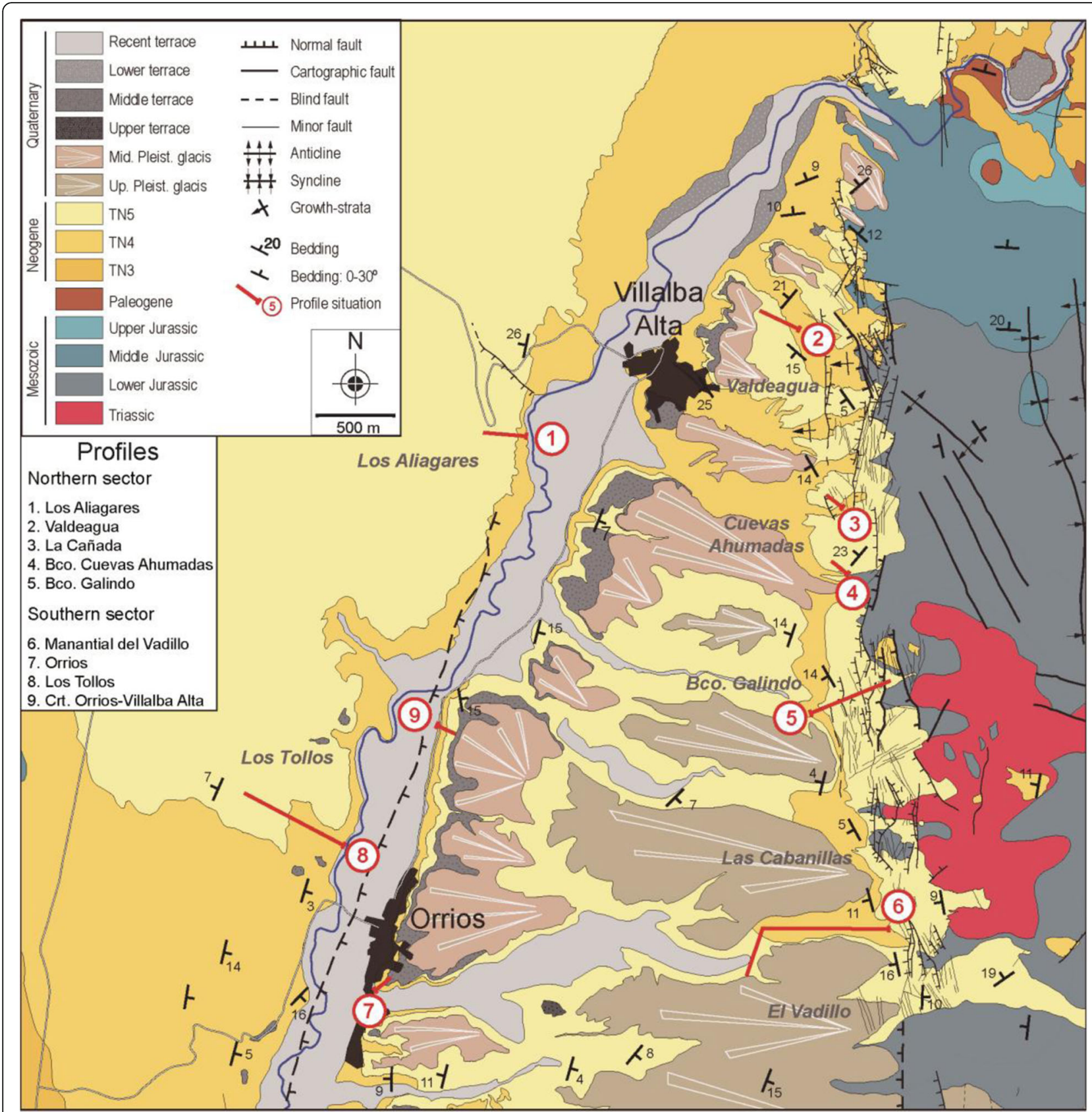

Fig. 2 Geological map of the northern sector of the Teruel Basin (see location on Fig. 1 b) with location of the nine stratigraphical profiles (1. Los Aliagares; 2. Valdeagua; 3. La Cañada; 4. Bco. de la Cuevas Ahumadas; 5. Bco. Galindo; 6. Manantial del Vadillo; 7. Orrios; 8. Los Tollos; 9. Orrios-Villalba Alta road)

McLane 1995); location of outsized clasts also supports this interpretation. During episodes of waning discharge water flows were restricted into low sinuosity channels. Gravel beds with trough cross bedding indicate multiepisodic channels, and horizontal bedding suggests longitudinal gravel bar development. Tabular fine deposits are related to poorly developed flooding areas. Matrixsupported conglomerates forming coarsening upwards cycles represent debris flows and suggest poorly vegetated slopes (Bull 1972; Hampton 1979).
Lithofacies CS and CM represent deposition in middle alluvial sectors dominated by perennial-semiperennial tractive flows in non-sinuous, multiepisodic channels, and lateral unconfined flows (Table 1, Fig. 4). Longitudinal, and sometimes transverse, gravel bar migration occurred during high-energy flow episodes (Hein and Walker 1977; Miall 1978, 1985) with sand beds representing deposition on top bars or in channels mainly during waning discharges (Galloway and Hobday 1983). The finest deposits indicate floodplain development and 


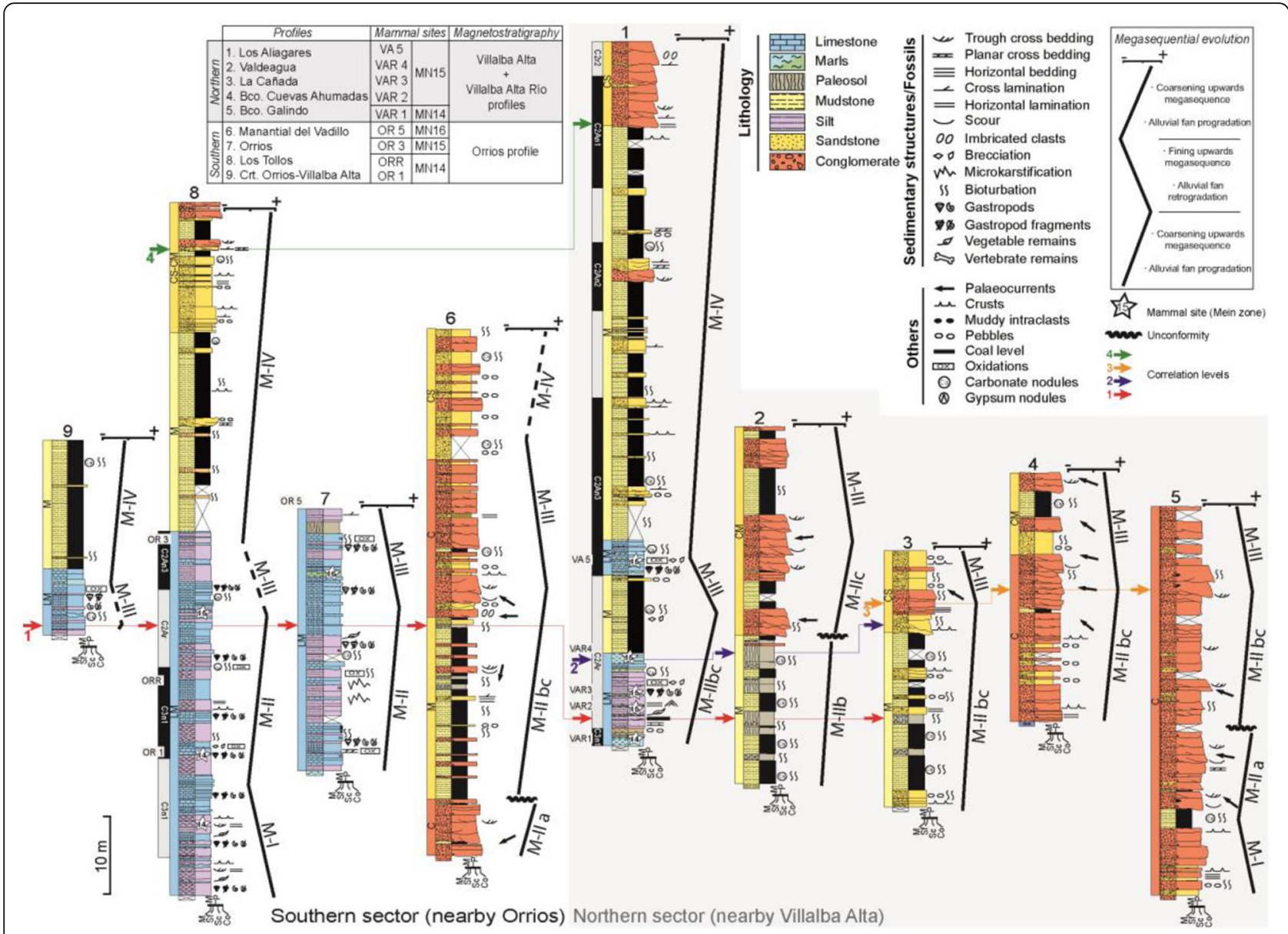

Fig. 3 Stratigraphical correlation sketch. Profiles correspond to two approximately W-E trending cross-sections, nearby Villalba Alta and Orrios, respectively (see Fig. 2 for location). Megasequential evolution based on grain size changes and lithofacies associations have been drawn for each profile. Correlation levels, mammal localities with their corresponding Mammal Neogene (MN) zones (see Table 2), and the composite Villalba Alta-Villalba Alta Río and Orrios magnetostratigraphic profiles of Opdyke et al. (1997) (see stratigraphic profiles 1 and 8, respectively) are also shown

prevented lateral channel migration; in these areas subaerial exposure episodes favoured root bioturbation.

Lithofacies $\mathrm{M}$ represents deposition in the most distal alluvial sectors (Table 1, Fig. 4). Cyclically exposed mudflat areas were fed by unconfined, suspensiondominated flows, but some isolated conglomerate channels reached these areas during high-energy water discharges. A near-surface water level in mudflats favoured vegetation and root activity, as well as genesis of carbonate nodules that suggest arid to semiarid climate conditions (Alonso-Zarza et al. 1992; Alonso-Zarza 2003). Rare limestone in this lithofacies generated in shallow fresh-water ponds, probably indicating episodes of more humid conditions.

Finally, lithofacies LM (Table 1, Fig. 4) represents deposition in shallow fresh-water, low-energy lacustrine-palustrine areas, rich in gastropods and fringed by rooted vegetation (Wrigth 1990; Platt and Wright 1991; Gierlowski-Kordesch 2010). This facies is carbonate precipitation-dominated but detrital (silt and mud sizes) supplies also reached the lake.
Inner lacustrine areas are charecterised by massive limestone, whereas in palustrine fringes bioturbation and brecciation processes were common. Interbedded lignite levels are evidence of plant-derived organic matter deposition and anoxic conditions during some periods.

The stratigraphical correlation has permited lateral and vertical relationships between lithofacies to be established (Fig. 5), and two main sedimentary systems, alluvial fan and lacustrine-palustrine, to be defined. Alluvial fans developed along the eastern basin margin, and display a fast transition between proximal and distal sectors, as well as towards the palustrine areas.

Two sets of alluvial fans can be distinguished considering the radius length and sourcing areas (Figs. 5 and 6). Small alluvial fans (SAF), fed by the footwall of NNWSSE faults, are up to $5 \mathrm{~km}$ long and show westwarddirected palaeocurrents, whereas very small alluvial fans (VSAF), shorter than $1 \mathrm{~km}$, are mainly northwestdirected and fed by NNE-SSW faults. Basinwards, lithofacies LM (Table 1, Fig. 4) represents shallow, low-energy, 
Table 1 Lithofacies associations distinguished for the Pliocene-Pleistocene record in the northern sector of the Teruel Basin

\begin{tabular}{|c|c|c|c|c|}
\hline Lithofacies association & Lithology & Texture & $\begin{array}{l}\text { Geometry and sedimentary } \\
\text { structures }\end{array}$ & Interpretation \\
\hline \multirow[t]{3}{*}{ Conglomerate (C) } & $\begin{array}{l}\text { Conglomerate } \\
(90 \%-100 \%)\end{array}$ & $\begin{array}{l}\text { Clast or matrix supported } \\
\text { textures and subangular } \\
\text { to subrounded carbonate } \\
\text { and siliceous cobbles to } \\
\text { boulders. Local outsized } \\
\text { clasts. Fine sandy or muddy } \\
\text { matrix, the later in matrix- } \\
\text { supported, coarsening- } \\
\text { upwards, bodies. }\end{array}$ & $\begin{array}{l}\text { Tabular bodies and rare } \\
\text { channelled bases. Clast } \\
\text { supported deposits with } \\
\text { internal irregular surfaces, } \\
\text { horizontal- bedding, and } \\
\text { rare trough cross-bedding. }\end{array}$ & \multirow[t]{3}{*}{$\begin{array}{l}\text { Alluvial fan-proximal sector } \\
\text { dominated by flash floods } \\
\text { and debris flows. During } \\
\text { waning discharges some } \\
\text { channels with longitudinal } \\
\text { bars developed; overbank } \\
\text { areas poorly preserved. }\end{array}$} \\
\hline & $\begin{array}{l}\text { Sandstone } \\
(0-10 \%)\end{array}$ & $\begin{array}{l}\text { Coarse-grained with polygenic } \\
\text { pebbles and cobbles. }\end{array}$ & $\begin{array}{l}\text { Decimetric tabular or } \\
\text { irregular bodies with } \\
\text { trough cross-bedding } \\
\text { and cross lamination. }\end{array}$ & \\
\hline & $\begin{array}{l}\text { Mudstone } \\
(0-10 \%)\end{array}$ & $\begin{array}{l}\text { Massive with disperse polygenic } \\
\text { pebbles and cobbles. }\end{array}$ & $\begin{array}{l}\text { Decimetric tabular or } \\
\text { irregular bodies. }\end{array}$ & \\
\hline \multirow[t]{2}{*}{$\begin{array}{l}\text { Conglomerate and } \\
\text { Sandstone (CS) }\end{array}$} & $\begin{array}{l}\text { Conglomerate } \\
(50 \%-60 \%)\end{array}$ & $\begin{array}{l}\text { Clast-supported subangular } \\
\text { to rounded carbonate and } \\
\text { siliceous pebbles and cobbles } \\
\text { with fine to medium-grained } \\
\text { sandy matrix. }\end{array}$ & $\begin{array}{l}\text { Tabular or channelled } \\
\text { bodies with horizontal } \\
\text { and trough cross-bedding. } \\
\text { Common fining-upwards } \\
\text { cycles. }\end{array}$ & \multirow{2}{*}{$\begin{array}{l}\text { Alluvial fan-middle sector with } \\
\text { channelled, sometimes } \\
\text { unconfined flows and gravel } \\
\text { bars. Sandstones represent } \\
\text { deposition during waning water } \\
\text { discharges and root traces } \\
\text { non-sedimentation episodes. }\end{array}$} \\
\hline & $\begin{array}{l}\text { Sandstone } \\
(40 \%-50 \%)\end{array}$ & $\begin{array}{l}\text { Coarse to medium-grained } \\
\text { sandstone with disperse } \\
\text { pebbles and cobbles. }\end{array}$ & $\begin{array}{l}\text { Decimetric-metric tabular } \\
\text { or channelled bodies with } \\
\text { trough cross-bedding and } \\
\text { rare root traces and } \\
\text { carbonate nodules. }\end{array}$ & \\
\hline \multirow[t]{3}{*}{$\begin{array}{l}\text { Conglomerate and } \\
\text { Mudstone }(C M)\end{array}$} & $\begin{array}{l}\text { Conglomerate } \\
(70 \%-90 \%)\end{array}$ & $\begin{array}{l}\text { Clast-supported subrounded to } \\
\text { rounded carbonate and siliceous } \\
\text { pebbles and cobbles with fine } \\
\text { to medium-grained sandy matrix. }\end{array}$ & $\begin{array}{l}\text { Channels with gently } \\
\text { channelled internal } \\
\text { surfaces and trough, } \\
\text { and less common, } \\
\text { planar cross-bedding. } \\
\text { Some tabular beds. }\end{array}$ & \multirow[t]{3}{*}{$\begin{array}{l}\text { Alluvial fan-middle sector with } \\
\text { straight multiepisodic channels } \\
\text { commonly overflooded. Well- } \\
\text { developed overbank areas that } \\
\text { prevented channel migration. }\end{array}$} \\
\hline & $\begin{array}{l}\text { Mudstone } \\
(10 \%-30 \%)\end{array}$ & $\begin{array}{l}\text { Massive with rare dispersed } \\
\text { pebbles and cobbles. }\end{array}$ & $\begin{array}{l}\text { Decimetric tabular bodies } \\
\text { with common root traces. }\end{array}$ & \\
\hline & $\begin{array}{l}\text { Sandstone } \\
(0-10 \%)\end{array}$ & $\begin{array}{l}\text { Medium-grained sandstones } \\
\text { with disperse pebbles and } \\
\text { cobbles. }\end{array}$ & Mainly decimetriic tabular bodies. & \\
\hline \multirow[t]{4}{*}{ Mudstone (M) } & $\begin{array}{l}\text { Mudstone } \\
(70 \%-100 \%)\end{array}$ & Massive or bioturbated. & Metric tabular bodies. & \multirow{4}{*}{$\begin{array}{l}\text { Alluvial fan-distal sector mudflat } \\
\text { areas fed by unconfined water } \\
\text { flows and episodically reached } \\
\text { by isolated shallow channels. Near- } \\
\text { surface water level favoured } \\
\text { pedogenic processes and soils but } \\
\text { local freshwater ponds also existed. }\end{array}$} \\
\hline & $\begin{array}{l}\text { Palaeosol } \\
(0-30 \%)\end{array}$ & $\begin{array}{l}\text { Carbonate palaeosols with } \\
\text { prismatic and rare nodular } \\
\text { structure. Disperse carbonate } \\
\text { or siliceous pebbles. }\end{array}$ & $\begin{array}{l}\text { Decimetric-metric tabular } \\
\text { bodies. }\end{array}$ & \\
\hline & $\begin{array}{l}\text { Limestone } \\
(0-10 \%)\end{array}$ & $\begin{array}{l}\text { Massive, bioturbated or } \\
\text { brecciated mudstone- } \\
\text { wackestone with common } \\
\text { gastropods. }\end{array}$ & Decimetric tabular bodies. & \\
\hline & $\begin{array}{l}\text { Conglomerate } \\
(0-5 \%)\end{array}$ & $\begin{array}{l}\text { Clast-supported rounded } \\
\text { polygenic pebbles with very } \\
\text { fine sandy matrix. }\end{array}$ & $\begin{array}{l}\text { Decimetric poorly channelled } \\
\text { or tabular bodies with occasional } \\
\text { irregular internal surfaces. }\end{array}$ & \\
\hline \multirow[t]{3}{*}{$\begin{array}{l}\text { Limestone and } \\
\text { Marl (LM) }\end{array}$} & $\begin{array}{l}\text { Limestone } \\
(30 \%-60 \%)\end{array}$ & $\begin{array}{l}\text { Massive, bioturbated or } \\
\text { brecciated mudstone-packstone } \\
\text { with gastropods, ostracods, } \\
\text { charophytes and vegetal } \\
\text { remains. Rare coal layers. }\end{array}$ & $\begin{array}{l}\text { Decimetric-metric tabular, } \\
\text { irregular or slightly lenticular } \\
\text { bodies with occasional } \\
\text { symmetric ripples. }\end{array}$ & \multirow[t]{3}{*}{$\begin{array}{l}\text { Shallow lacustrine-palustrine } \\
\text { areas with alternating episodes } \\
\text { of carbonate precipitation and } \\
\text { detrital deposition. Marginal exposed } \\
\text { areas with rooted vegetation. } \\
\text { Frequent water-level oscillations. }\end{array}$} \\
\hline & Marl (40\%-70\%) & $\begin{array}{l}\text { Massive or laminated with } \\
\text { common gastropods and } \\
\text { spherical carbonate nodules. }\end{array}$ & $\begin{array}{l}\text { Decimetric-metric tabular or } \\
\text { irregular bodies. }\end{array}$ & \\
\hline & $\begin{array}{l}\text { Mudstone } \\
(0-10 \%)\end{array}$ & Massive. & Decimetric tabular bodies. & \\
\hline
\end{tabular}




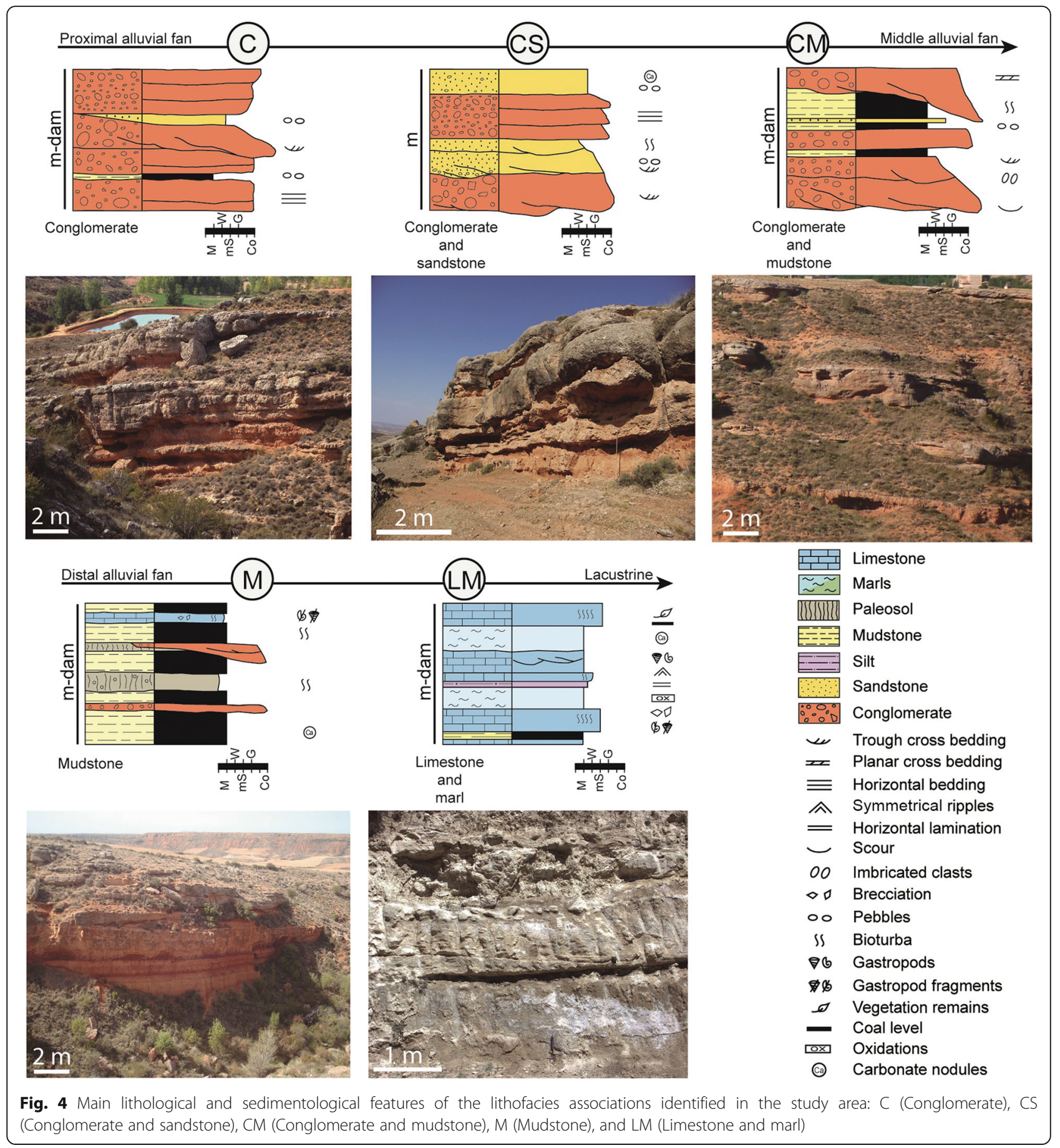

fresh-water lakes and palustrine fringes. Although lakes were dominated by carbonate precipitation, they also received detrital supplies from the alluvial fans.

\subsubsection{Megasequential evolution}

Based on changes of both grain-size and lithofacies associations, four megasequences (M-I to M-IV) have been defined (Figs. 3 and 5). M-I and M-III represent retrogradation of alluvial fans sourced in the eastern margin, while M-II and M-IV were generated during alluvial progradation (Fig. 5). The most recent deposits (M-IV) are mainly preserved in the central parts of the basin (sections 1,8,9; Figs. 2, 3 and 5), although the correlation reveals that the top of section 6 also corresponds to MIV. Boundaries between these sequences correspond to stratigraphical trend variations, changing from alluvial retrogradation to progradation (B-I and B-III) or vice versa (B-II). The B-I stratigraphic boundary represents 


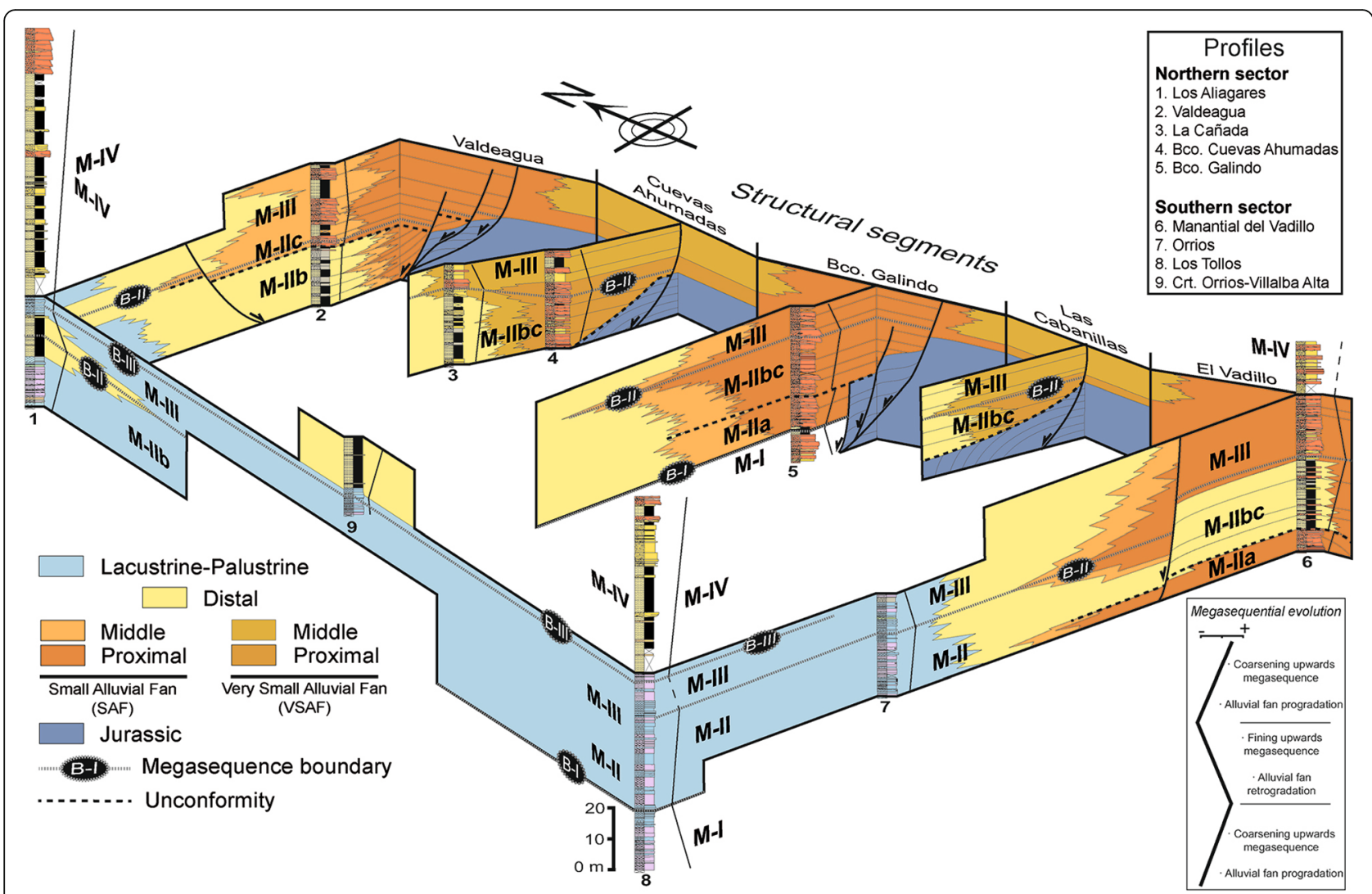

Fig. 5 Stratigraphical correlation sketch. Megasequential evolution for each profile and geometrical relationships (e.g., unconformities, onlaps) between units and faults are also shown. See text for explanation. Lateral and vertical relationships between lithofacies associations have permitted two types of alluvial fans to be differentiated: small alluvial fans (SAF) and very small alluvial fans (VSAF)

the maximum alluvial retrogradation and associated lacustrine expansion affecting the whole Teruel Basin (Ezquerro 2017).

The proximal alluvial deposits include a more heterogeneous evolution, and far from the margin, in the lacustrine deposits, the stratigraphic evolution is blurred. In many zones, M-II megasequence (Figs. 3 and 5) shows a complex evolutionary pattern (e.g., profiles 2, 5 or 6). Local angular unconformities allow dividing it into three parts (M-IIa, M-IIb, and M-IIc) that cannot be distinguished in other sections (Fig. 3).

\subsubsection{Megasequence dating}

Dating of megasequences has been mainly based on mammal biostratigraphy and magnetostratigraphy data but also on the stratigraphical correlation. Ten mammal localities studied by Weerd (1976), Adrover (1986) and Mein et al. (1983, 1990), yielding faunas from mammal zones MN14 to MN16 (Table 2), have been now positioned in their precise stratigraphical location within our sections (Fig. 3). Magnetostratigraphic data come from three profiles (Villalba Alta, Villalba Alta Río and Orrios) carried out by Opdyke et al. (1997). These profiles have now been revised in detail in order to enable correlation and provide aproximate absolute age for the studied sedimentary succesion and the megasequence boundaries. Due to their proximity, the Villalba Alta and Villalba Alta Rio magnetostratigraphic profiles have been correlated with our stratigraphic section 1 (Los Aliagares); since they show a little stratigraphic superposition in the base of the C2an3n chron, a merged, composite magnetostratigraphic profile was constructed (see profile 1 in Fig. 3). In the same way, the Orrios magnetostratigraphic profile was correlated with our section 8 (Los Tollos, Fig. 3).

All these data have allowed a precise dating of the studied stratigraphic succession (Fig. 7), which ranges from Early Pliocene ( 4.6 Ma; middle Zanclean/early Ruscinian) to earliest Pleistocene $(\sim 2.4 \mathrm{Ma}$; basal Gelasian/midle Villafranchian). The B-I stratigraphic boundary has been dated to $\sim 4.4 \mathrm{Ma}$ (middle Zanclean/early Ruscinian, MN14). The B-II boundary corresponds to MN15, in the late Ruscinian/late Zanclean $(\sim 3.7 \mathrm{Ma})$. The B-III boundary has been 


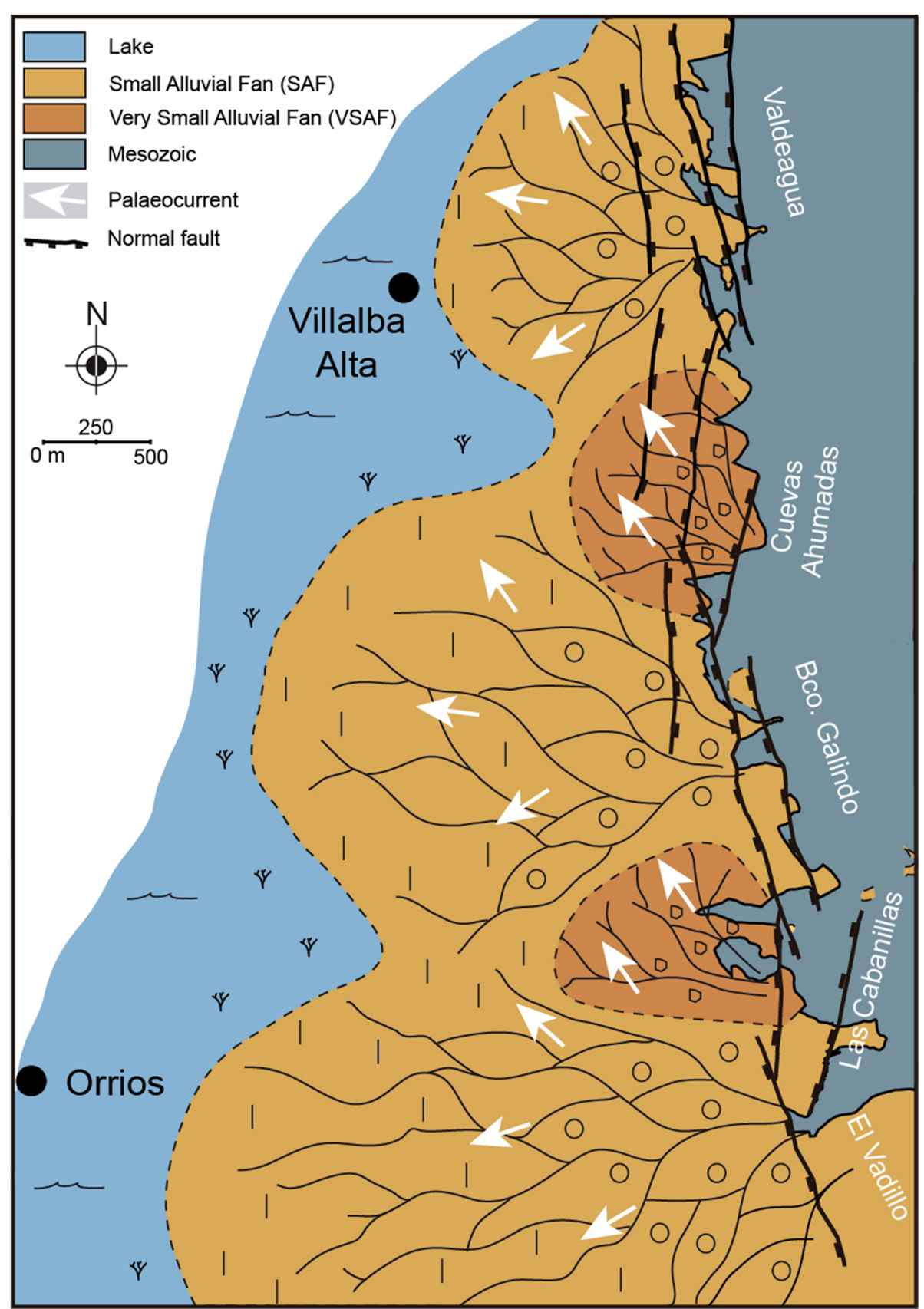

Fig. 6 Paleogeographical sketch of the studied area (transition between megasequences M-IIc and M-III) showing, in the eastern active margin small (SAF) and very small (VSAF) alluvial fans that interfer with lacustrine-palustrine areas towards the basin centre. Note the different paleocurrent pattern (white arrows) inferred for each type of alluvial fan

dated to $\sim 3.5 \mathrm{Ma}$ (basal Piazencian/basal Villafranchian; basal MN16), coeval of the achievement of the main FES. Because boundaries between M-IIa, M-IIb and $\mathrm{M}$-IIc were recognised in proximal deposits, they are much more difficult to be precisely dated; their ages likely correspond to uppermost MN14, and middle MN15 mammal zones, respectively.

\subsection{Structure, fracturing and stresses}

\subsubsection{Overall structure of the El Pobo fault zone}

The El Pobo Fault Zone constitutes the eastern, active margin in the northernmost sector of the Teruel graben. Mesozoic rocks of El Pobo Range are put into contact with Neogene deposits of the Teruel Basin, giving rise to a nearly rectilinear, $\mathrm{N}-\mathrm{S}$ trending mountain front 
Table 2 Mammal localities compiled from literature (see Fig. 3 for stratigraphic location within the studied stratigraphic record). The following information is given for each mammal locality: acronym and complete name, reference, Mammal Neogene unit (MN; Mein 1975; Agustí et al. 2001), and mammal guide taxons

\begin{tabular}{llcl}
\hline Mammal locality & Reference & MN Unit & Mammal guide taxon \\
\hline OR 8 (Orrios 8) & Mein et al. (1983, 1990) & 16 & Mimomys cf. polinicus and Mimomys (Kislangia) ichus \\
OR 5 (Orrios 5) & Weerd (1976), Mein et al. (1983, 1990) & & Mimomys stehlini, Mimomys gracilis, and Mimomys hajnackensis \\
VA 5 (Villalba Alta 5) & Mein et al. (1990) & 15 & Dolomys and Mimomys occitanus \\
OR 3 (Orrios 3) & Adrover (1986) & Mimomys archaiques \\
VAR 4 (Villalba Alta Río 4) & Mein et al. (1990) & \\
VAR 3 (Villalba Alta Río 3) & Mein et al. (1990) & & \\
VAR 2 (Villalba Alta Río 2) & Mein et al. (1990) & Trilophomys \\
VAR 1 (Villalba Alta Río 1) & Mein et al. (1990) & & \\
ORR (Orrios) & Weerd (1976) & & \\
OR 1 (Orrios 1) & Mein et al. (1990) &
\end{tabular}

about $15 \mathrm{~km}$ long (Fig. 1b). Its existence as a single, westdipping fault is commonly assumed in the literature (Moissenet 1983; Simón 1983; Gutiérrez et al. 2008), but it had not been previously mapped, probably due to the poor exposure of the fault trace. Recently, Liesa (2011a) and Ezquerro (2017) proposed a basin margin defined by several nearly parallel, NNW-SSE striking faults (El Pobo Fault Zone) and probably other NE-SW trending faults.
The overall structure makes a $\mathrm{N} 175^{\circ} \mathrm{E}$ trending basin boundary, which in cross-section view (Fig. 1c) represents a faulted monocline. The total vertical displacement accommodated by El Pobo Fault Zone at the Villalba Alta latitude, as inferred from offset of the FES and IES planation surfaces (Fig. 1c) and its correlative stratigraphic surfaces (Ezquerro 2017; Liesa et al. 2019a), attains $740 \mathrm{~m}$ for the total period of basin development (since the beginning

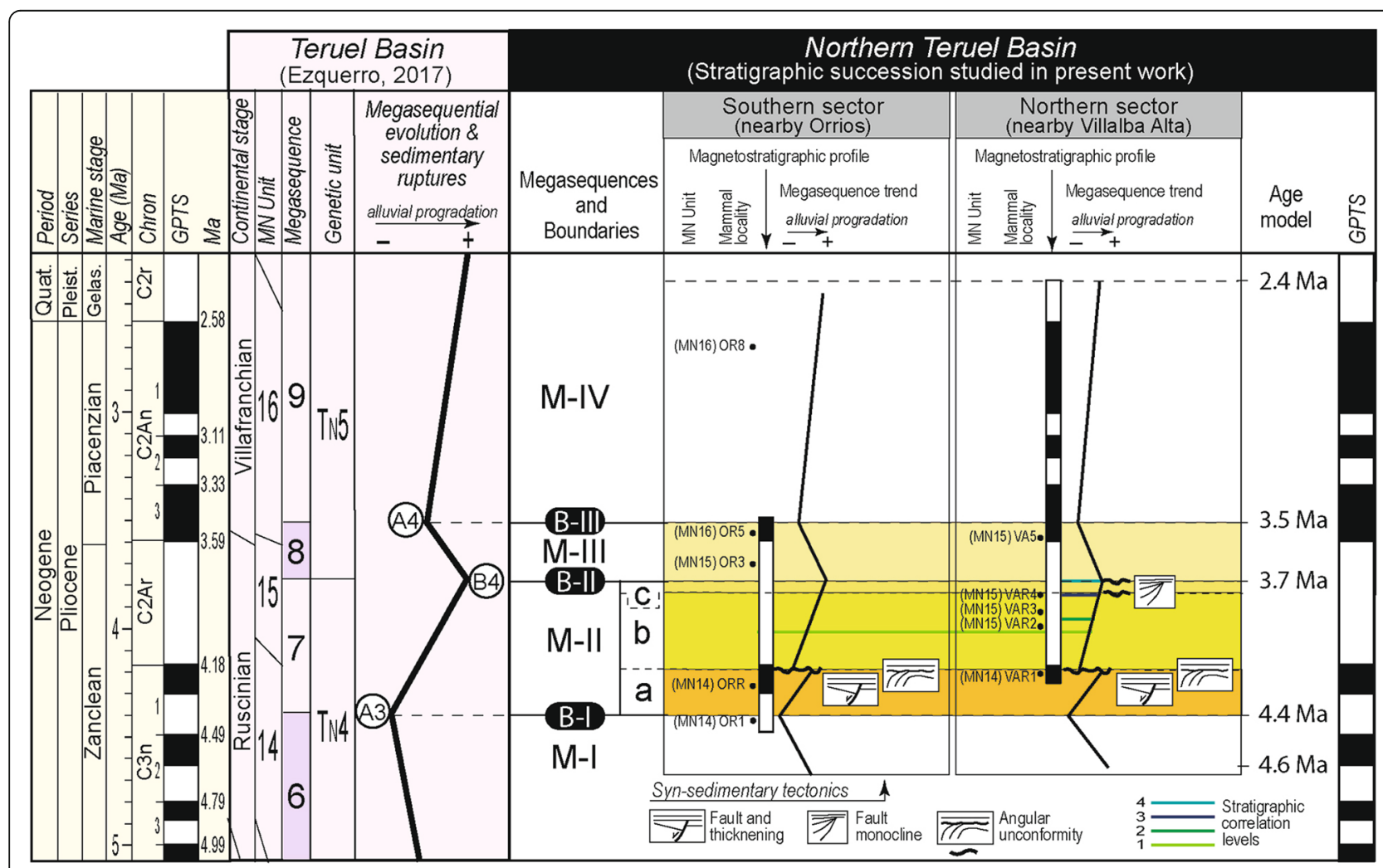

Fig. 7 Chronostratigraphic panel and megasequence evolution for the studied stratigraphic succession in the northern sector of the Teruel Basin (Orrios and Villalba Alta sectors). The relationships with the overall Teruel Basin are also shown 

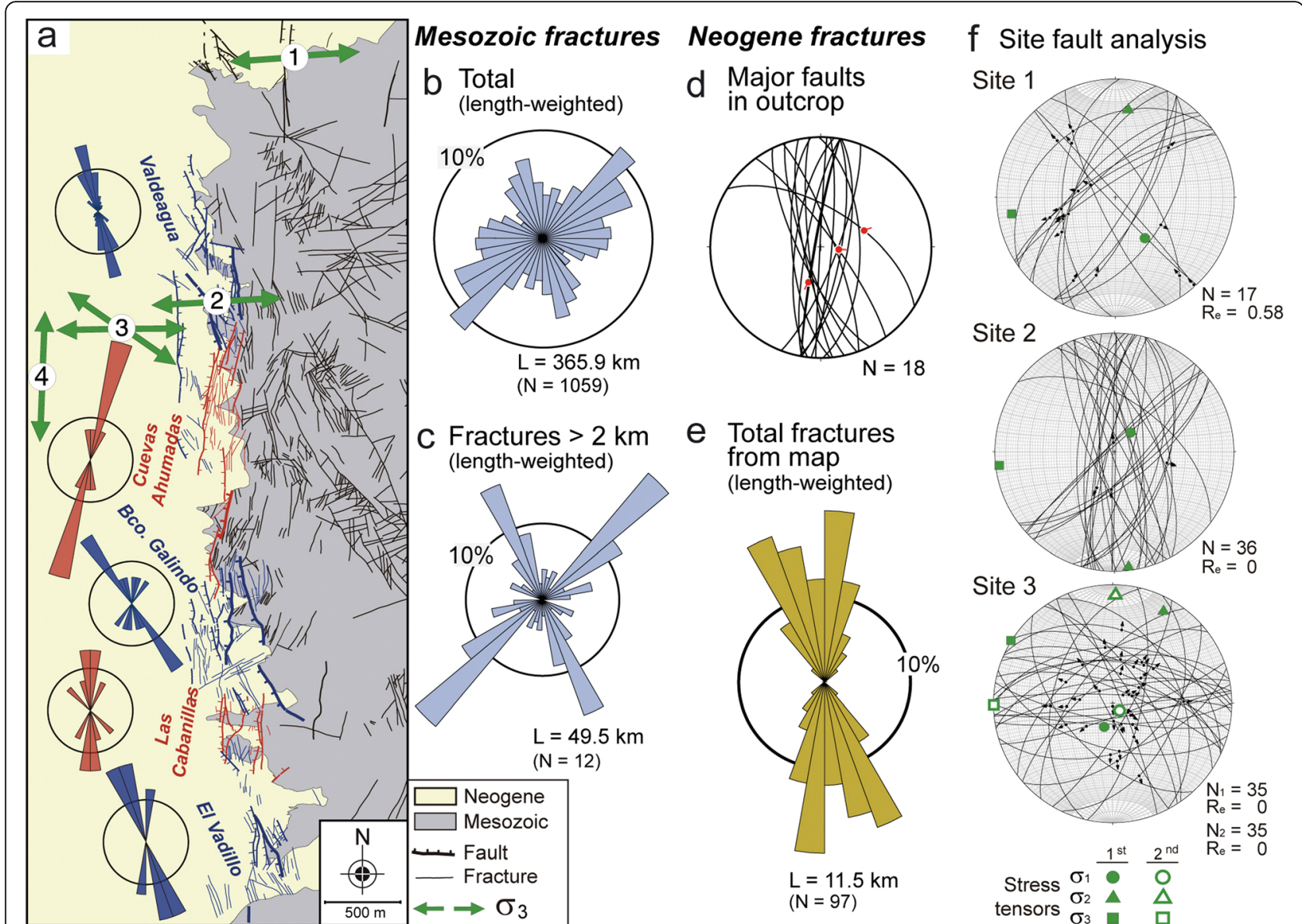

Fig. 8 a Synthetic structural map of the studied region showing the zigzag basin margin with alternating NNW-SSE and NNE-SSW trending segments; rose diagrams show the distribution of fault strikes measured on outcrop scale within each segment; $\mathbf{b}$ Rose diagram showing trend distribution of faults and fractures mapped in Mesozoic rocks, weighted according to their length; c Idem for fault traces with length over 2 km. Rose diagramas b and c after Liesa (2011b); d Stereoplot (equal area, low hemisphere) of fault planes and slickenlines measured on outcrops where border faults are exposed; e Length-weighted rose diagram of faults and fractures mapped in Neogene deposits; $\mathbf{f}$ Paleostress results in Neogene deposits of the study area. Stereoplots (equal area, low hemisphere) show orientation of fault planes, slickenlines and inferred stress axes in sites 1, 2 and 3. Directions of the inferred $\sigma_{3}$ axes of extensional stress tensors (green arrows) are displayed on the map. Sites 1, 2 and 3 : this work. Site 4: after Arlegui et al. (2005)

of Late Miocene, 11.2 Ma), and $380 \mathrm{~m}$ for Late PlioceneQuaternary times (3.5 Ma).

The structure of the studied basin margin (Figs. 2 and 8a) depicts a non-linear, zigzag fault zone made of a number of NNW-SSE trending segments (named from north to south: Valdeagua, Galindo and El Vadillo segments), alternating with other shorter, NNE-SSW trending segments (Cuevas Ahumadas and Las Cabanillas segments).

Individual faults, usually synthetic with the half-graben boundary (Fig. 8a), are generally shorther than $1 \mathrm{~km}$, and show offsets of several tens of meters. Although scarce, slickenlines and other kinematic indicators show consistent normal movements (Fig. 8d). The main fault planes juxtapose Mesozoic rocks against the Neogene deposits. Other numerous synthetic, steeply west-dipping normal faults cut both the folded Jurassic units and the gently tilted FES level within the footwall block. Antithetic minor faults have been recognized only in Pliocene materials, with dips of $70-78^{\circ} \mathrm{E}$ and offsets $<10 \mathrm{~m}$. Their position and size suggest that they accommodate longitudinal elongation in rollover bend folds associated to the main, synthetic faults.

The overall structure of the Neogene units is a strongly asymmetric syncline. Its western limb represents the gentle rollover monocline asociated to the El Pobo Fault Zone, dipping eastward usually in the range of $2-3^{\circ}$ (locally up to $12^{\circ}$ ). The eastern, shorter limb represents the accommodation bend at the active margin, with usual dips of about $20^{\circ} \mathrm{W}$. Stronger deformation is usually recognized in the lower beds cropping out near the active margin, in the form of either pure brittle offset or drag folds (see below). Deformation usually 
attenuates upward, indicating that extensional tectonics was coeval with deposition of Pliocene beds.

\subsubsection{Fractures in Mesozoic and Neogene rocks}

Mesozoic rocks of the footwall block (El Pobo Range) show a dense network of fractures (faults and large joints), several tens of metres to $6 \mathrm{~km}$ long (Liesa 2011b; Ezquerro 2017; Liesa et al. 2019a). Their azimuth distribution (Fig. 8b) shows a high dispersion, although a main set oriented NE-SW $\left(040^{\circ}-070^{\circ}\right)$ prevails. The rest of fractures are mostly distributed along E-W $\left(080^{\circ}-\right.$ $\left.100^{\circ}\right)$ and NNW-SSE $\left(330^{\circ}-350^{\circ}\right)$ directions. If only faults longer than $2 \mathrm{~km}$ are computed, two noticeable sets trending NE-SW $\left(040^{\circ}-050^{\circ}\right)$ and NNW-SSE $\left(330^{\circ}-\right.$ $340^{\circ}$ ) are distinguished (Fig. 8c).

Large faults in Neogene rocks linked to the basin boundary show two conspicuous maxima close to N-S $\left(000^{\circ}-010^{\circ}\right)$ and NNW-SSE $\left(330^{\circ}-350^{\circ}\right)($ Fig. $8 d$, e). Both fault sets are spatially distributed among the distinct fault segments in accordance with the zigzag pattern of the basin margin (Fig. 8a).

\subsubsection{Stress systems}

The predominance of nearly N-S and NNW-SSE striking faults in Neogene materials suggests that they have been activated under an extensional stress field with dominant $\sigma_{3}$ trajectories close to E-W. Paleostress analysis achieved in three mesostructural sites of Vallesian (site 1) and Late Ruscinian rocks (sites 2 and 3) corroborates this interpretation, since the azimuths of most of the inferred $\sigma_{3}$ axes are close to E-W (azimuth 086-089; Table 3 and Fig. 8a, f). Only a second (earlier) stress tensor inferred in site 3 shows a WNW-ESE (azimuth 125) trending $\sigma_{3}$ axis. In all cases the maximum stress axis $\left(\sigma_{1}\right)$ is nearly vertical, while the low values of stress ratio $R_{e}=\left(\sigma_{2}-\sigma_{3}\right) /\left(\sigma_{1}-\sigma_{3}\right)$ indicate a 'multidirectional' extensional regime. An additional stress tensor obtained in the study area by Arlegui et al. (2005) (site 4 in Fig. 8a and Table 3 ) shows a $\sigma_{3}$ axis trending $\mathrm{N}$ $\mathrm{S}$ (004) suggesting local switching of $\sigma_{2}$ and $\sigma_{3}$ axes.

\subsection{Tectono-sedimentary framework}

Evidence of the close relation between tectonics and sedimentation is the association of alluvial fans to faults in the basin margin (Figs. 5 and 6). Small alluvial fans (SAF), wider southwards, spread from NNW-SSE trending fault segments, while very small alluvial fans (VSAF) spread from the NNE-SSW ones and directly lie on Jurassic rocks, with a general onlap arrangement. Paleocurrents also show different patterns (Fig. 6), radial (SW to NW directed flows) for SAF, and more constricted, mainly NW directed, for VSAF. Although small alluvial fans were generated previously, both types of fans coexisted during the last evolution stages, since M-IIb (MN15) (Figs. 5 and 6).

It is worth noting that deformation structures are mainly concentrated close to the basin margins and mainly associated to prograding MII alluvial deposits. In the margin, rollover, growth monoclinal and drag folds associated to faults mainly involve Pliocene deposits belonging to M-IIa to M-IIc; their detailed study suggests a succession of distinct styles in fault development. Several examples corresponding to selected exceptional outcrops with different geometrical relationships between Pliocene deposits, as well as with Mesozoic rocks, are described below; they have been grouped according to the structural trend of the fault segment considered.

\subsubsection{NNW-SSE segments}

El Vadillo segment At the Manantial del Vadillo outcrop, a decametre-scale normal fault, trending NNWSSE and dipping W (fault $\alpha$, Fig. 9a), puts into mechanic contact Jurassic and Pliocene rocks, with a minimum throw of $10 \mathrm{~m}$. Jurassic beds in the footwall block are tilted towards the fault zone $\left(<30^{\circ} \mathrm{W}\right)$, probably representing an associated drag monocline. Associated to the main fault, a tectonic breccia with disorganized Jurassic blocks and Pliocene boulders can be recognised. SAF conglomerate and sandstone include M-II (with IIa, IIb, and IIc) and M-III. Megasequence M-IIa is cut by several synthetic faults (faults $\beta$ and $\gamma$, Fig. 9a), which locally

Table 3 Palaeostress results. The following information is given for each data site: label used in this work; complete name; UTM coordinates, $X$ and $Y$; affected rocks (Lm: limestone, Mu: mudstone, St: sandstone, Co: conglomerate); age; azimuth of the horizontal $\sigma_{3}$ axis; stress ratio $R_{e}$ used by Etchecopar et al. (1981), and $R$ used by Bott (1959); chronological order of stress tensors (1, 2); mean angular misfit $\left({ }^{\circ}\right)$ between observed slip and the resolved shear stress from the computed stress solution; number of explained faults (n) in relation with the total number (N) of faults of the sample; analytical method used for stress inversion (ET: Etchecopar method, Li: Lisle et al. (2001) method). Site 4 after Arlegui et al. (2005)

\begin{tabular}{|c|c|c|c|c|c|c|c|c|c|c|c|}
\hline \multicolumn{2}{|c|}{ Site } & \multicolumn{2}{|l|}{ Location } & \multirow[t]{2}{*}{ Lithology } & \multirow[t]{2}{*}{ Age } & \multicolumn{3}{|l|}{ Stress state } & \multirow{2}{*}{$\begin{array}{l}\text { Angular } \\
\text { misfit }\left(\left(^{\circ}\right)\right.\end{array}$} & \multirow[t]{2}{*}{$\mathrm{n} / \mathrm{N}$} & \multirow{2}{*}{$\begin{array}{l}\text { Analysis } \\
\text { method }\end{array}$} \\
\hline$\overline{\mathrm{N}^{0}}$ & Name & Coord. X & $\overline{\text { Coord. Y }}$ & & & $\overline{\sigma_{3} \text { azimut }}$ & $\mathrm{R}_{\mathrm{e}}$ & $\mathrm{R}$ & & & \\
\hline 1 & Alcamines río & 673,795 & $4,500,189$ & $\mathrm{Mu}+\mathrm{St}$ & Vallesian & 086 & 0.58 & 1.72 & $6^{\circ}$ & $11 / 17$ & ET \\
\hline 2 & Villalba Alta macroestación & 673,265 & $4,498,417$ & $\mathrm{Mu}+\mathrm{Co}$ & Late Ruscinian & 087 & 0 & $\rightarrow \infty$ & & $20 / 36$ & $\mathrm{LI}$ \\
\hline 3 & Villalba Alta granja & 672,271 & $4,498,208$ & $\mathrm{Lm}$ & Late Ruscinian & $\begin{array}{l}125(1) \\
089(2)\end{array}$ & $\begin{array}{l}0 \\
0\end{array}$ & $\begin{array}{l}\rightarrow \infty \\
\rightarrow \infty\end{array}$ & $\begin{array}{l}8^{\circ} \\
10^{\circ}\end{array}$ & $\begin{array}{l}25 / 35 \\
26 / 35\end{array}$ & $\begin{array}{l}\mathrm{ET} \\
\mathrm{ET}\end{array}$ \\
\hline 4 & 13 Villalba Alta 1 & 671,947 & $4,497,718$ & $\mathrm{Lm}$ & Villafranchian & 004 & & & & $24 / 24$ & $\mathrm{LI}$ \\
\hline
\end{tabular}




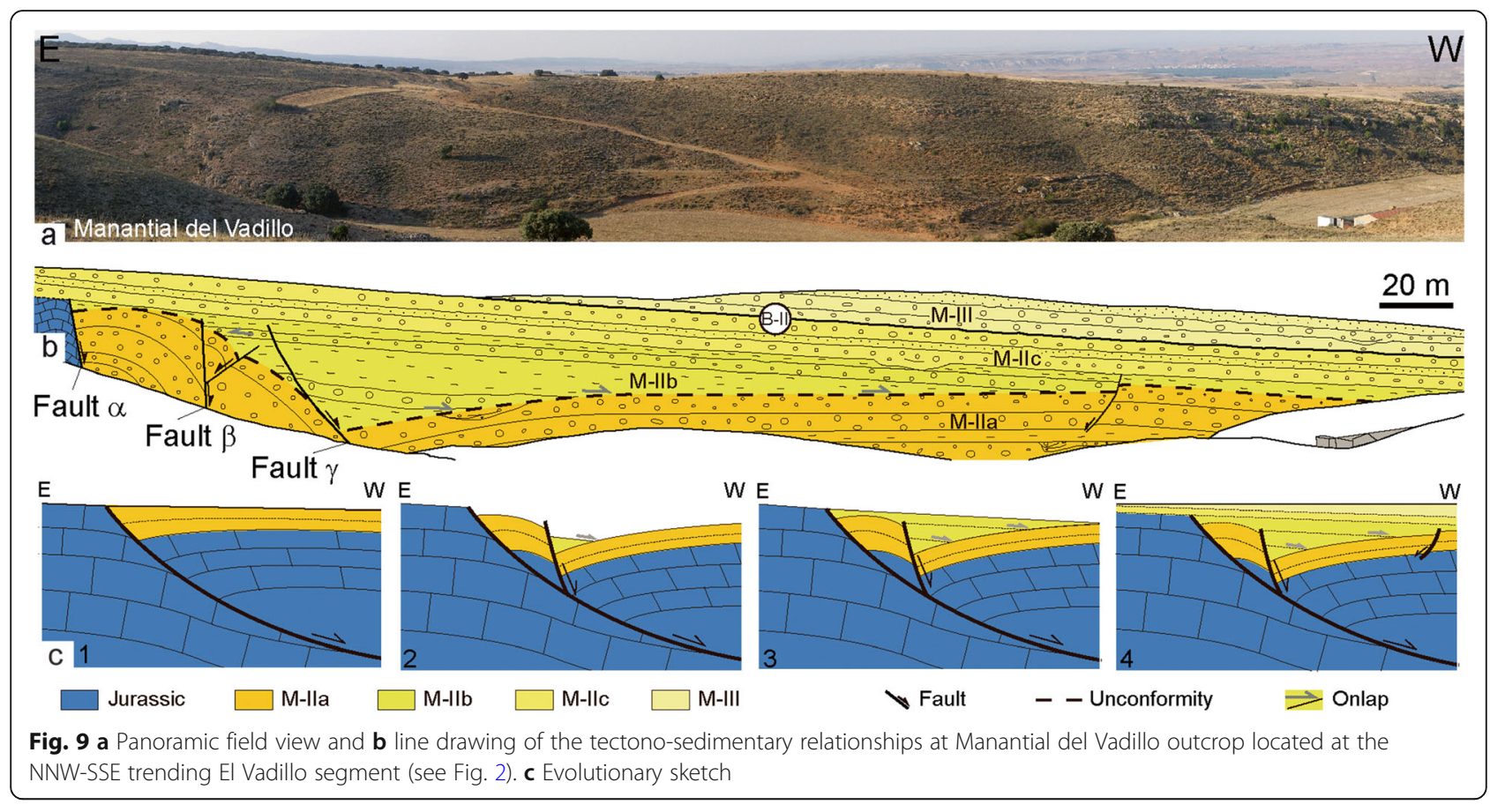

offset the lowermost beds of M-IIb. Between $\alpha$ and $\gamma$ faults, M-IIa dips westward, while towards the west it dips up to $22^{\circ} \mathrm{E}$ against the $\gamma$ fault plane, depicting a rollover geometry and forming a structural relief of ca. $20 \mathrm{~m}$-high. M-IIb, representing a rapid initial alluvial retrogradation, unconformably lies on M-IIa and displays an aggradational stack, onlapping M-IIa towards the west and east (buttress unconformity). Then, M-IIc indicates alluvial progradation overtaking the rollover hinge zone and covering the fault zone. Beds of M-III represent subsequent alluvial retrogradation.

These observations suggest the presence of a master fault at depth that splayed upwards into minor synthetic fault planes, according to the following evolutionay model (Fig. 9b): (1) during M-IIa deposition, displacement of the main fault increased the accommodation space, and alluvial deposits were preserved in its hanging-wall block; (2) sudden slip on the master fault $(\alpha)$ and synthetic minor faults ( $\beta$ and $\gamma$ ) occurred, enhancing the rollover geometry affecting M-IIa; (3) M-IIb beds filled the created trough and onlapped the structural highs, while local faulting occurred; (4) related to decreasing tectonic activity, M-IIc overlies the faults and represents a basinward progradation; finally, M-III records a subsequent retrogradation, undergoing tilting towards the basin centre.

Barranco Galindo segment This structure (Fig. 10) is similar to that described in El Vadillo, with two large, NNW-SSE faults $(\delta$ and $\varepsilon$ ) cutting SAF sediments. The coarsening-upwards M-IIa is only preserved in the downthrown block of fault $\varepsilon$. M-IIb is also coarsening upwards and indicates alluvial progradation; it shows a clear wedge shape, and undergoes tilting towards fault $d$. Its lower part shows an aggradational pattern and onlaps westwards on both Jurassic and M-IIa, and eastwards against the fault, while its upper part thickens against the fault plane. Megasequence M-IIc and then M-III cover the fault d, an onlap Jurassic rocks of the footwall. A footwall normal fault sequence, and creation of accommodation space coeval of both M-IIa and M-IIb deposition, can be interpreted from the described features. As in the previous case, M-IIb first filled the created trough and onlaped the structural highs, and M-IIc and M-III record decreasing tectonic activity.

Valdeagua segment At this segment several hectometre-scale NNW-SSE synthetic and antithetic faults affecting Jurassic rocks and Pliocene sediments crop out (Figs. 2 and 11). The Jurassic uplifted blocks show overall westwards tilting (commonly $<22^{\circ}$ ) and numerous fault planes with intense brecciation. On the basis of their sedimentological features and lateral continuity, Pliocene deposits have been associated to a SAF.

At the northern Valdeagua outcrop (Fig. 11a), the structure is similar to those of Barranco Galindo and Manantial del Vadillo, with a NNW-SSE striking, west dipping normal fault separating Jurassic from Pliocene rocks. The lower part of the syntectonic series (M-IIa proximal conglomerates) forms a rollover fold, and is onlapped by prograding M-IIb and M-IIc and retrograding M-III alluvial deposits. At the southern Valdeagua outcrop (Fig. 11b) the master fault becomes blind and 


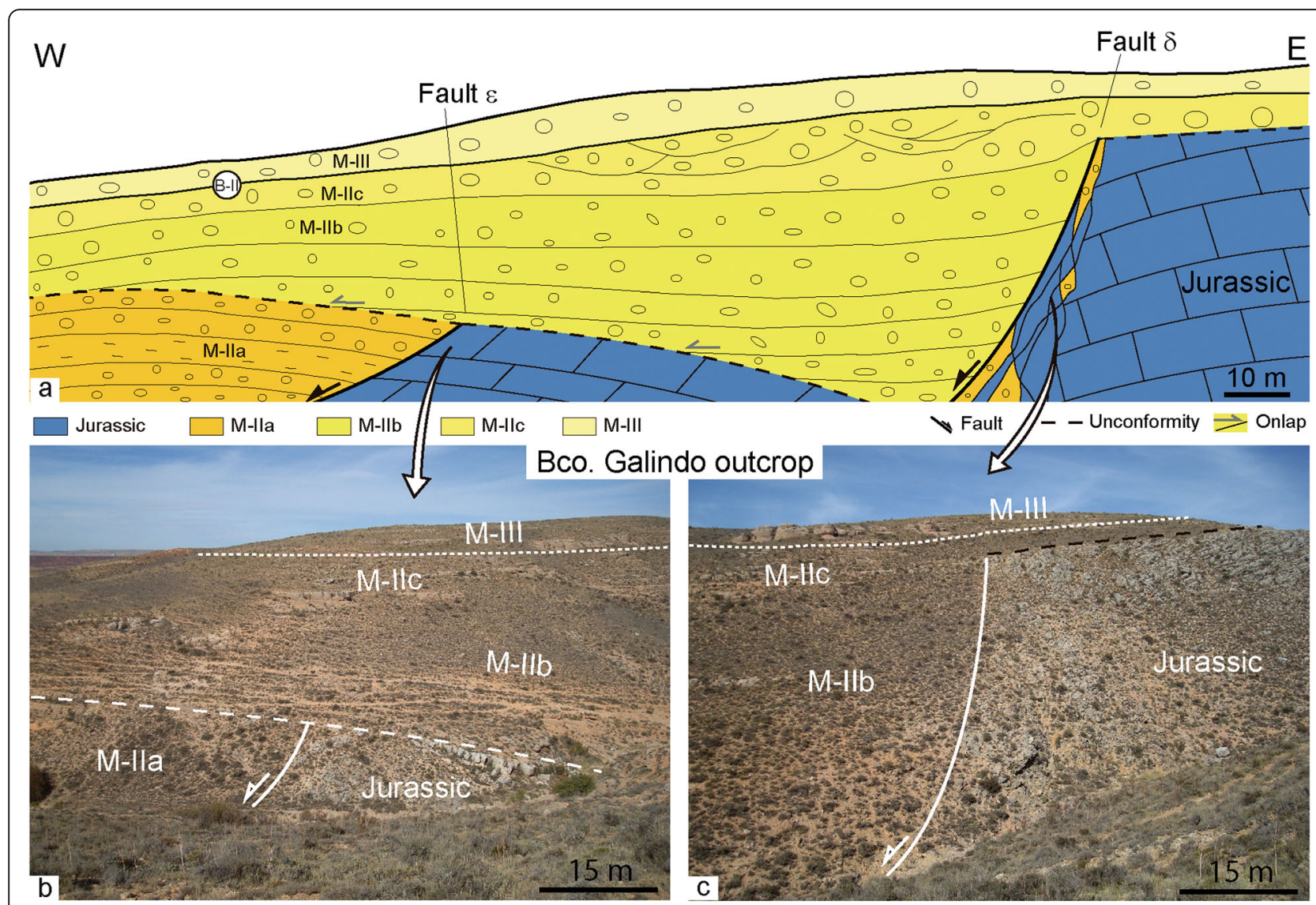

Fig. 10 a Line drawing of the tectono-sedimentary relationships at Barranco Galindo, within the NNW-SSE Barranco Galindo segment (location in Fig. 2); $\mathbf{b}$ and $\mathbf{c}$ Field views showing tectono-stratigraphic features around the two main faults $\varepsilon$ and $\delta$, respectively

the overall structure changes to a fault-propagation monocline. Bioturbated mudstones and calcretes belonging to M-IIb display westwards thickening and define an overall wedge-shaped geometry, the dip of lower beds being close to $45^{\circ} \mathrm{W}$ and progressively decreasing upwards (Fig. 11c). M-IIc evinces alluvial progradation, and unconformably overlies M-IIb deposits. M-IIc conglomerates thin towards the margin and are displaced $2-3 \mathrm{~m}$ by the master fault. To the west, a decametre-scale, synsedimentary NNWSSE striking antithetic fault offsets M-IIc and M-III, causing associated tilting (up to $25^{\circ} \mathrm{W}$ ) and thickening of some beds. These structural features have been interpreted as follows (see Fig. 11d): (1) initiation of propagation of a west-dipping blind fault and continuous activity coeval with M-IIb deposition; (2) continued upward propagation of the master fault and subsequent amplification of a wide fault-propagation monocline with synrift beds thickening basinwards; (3) propagation of the master fault cutting M-IIb, erosion near the fault tip, and sedimentation of M-IIc (which represents sharp alluvial progradation) and M-III; (4) propagation of both the master fault and an antithetic fault.

\subsubsection{NNE-SSW segments}

Cuevas Ahumadas segment At the Cuevas Ahumadas outcrop, a lower Pliocene calcrete (up to $3 \mathrm{~m}$ thick), corresponding to $\mathrm{M}$-IIa, rests with low-angle uncorformity on Jurassic limestones (Fig. 12a). It is overlain by M-IIb, northward tilted $\left(15-23^{\circ}\right)$, VSAF proximal conglomerates that towards the SSE onlap Jurassic limestones with slightly higher dip (up to $25-30^{\circ}$ ). Numerous NNE-SSW striking, mainly antithetic normal faults produce metreto decametre-scale offsets in both, Jurassic limestones and the base of M-IIb conglomerates. Faults vanish upwards and are overlain by the M-IIc conglomerates that represent an alluvial progradation. In contrast, the master, synthetic fault offsets the whole stratigraphic succession. Close to the fault plane a drag fold involves M-IIb conglomerate and Jurassic limestone beds (out of Fig. 12a). M-III retrograding deposits are also NW tilted with dip diminishing upwards.

The described features are interpreted as follows (Fig. 12b): (1) NW tilting of the Jurassic substratum and sediment by-pass, then probably representing the early evolutionary stage of a relay ramp between the NNW- 


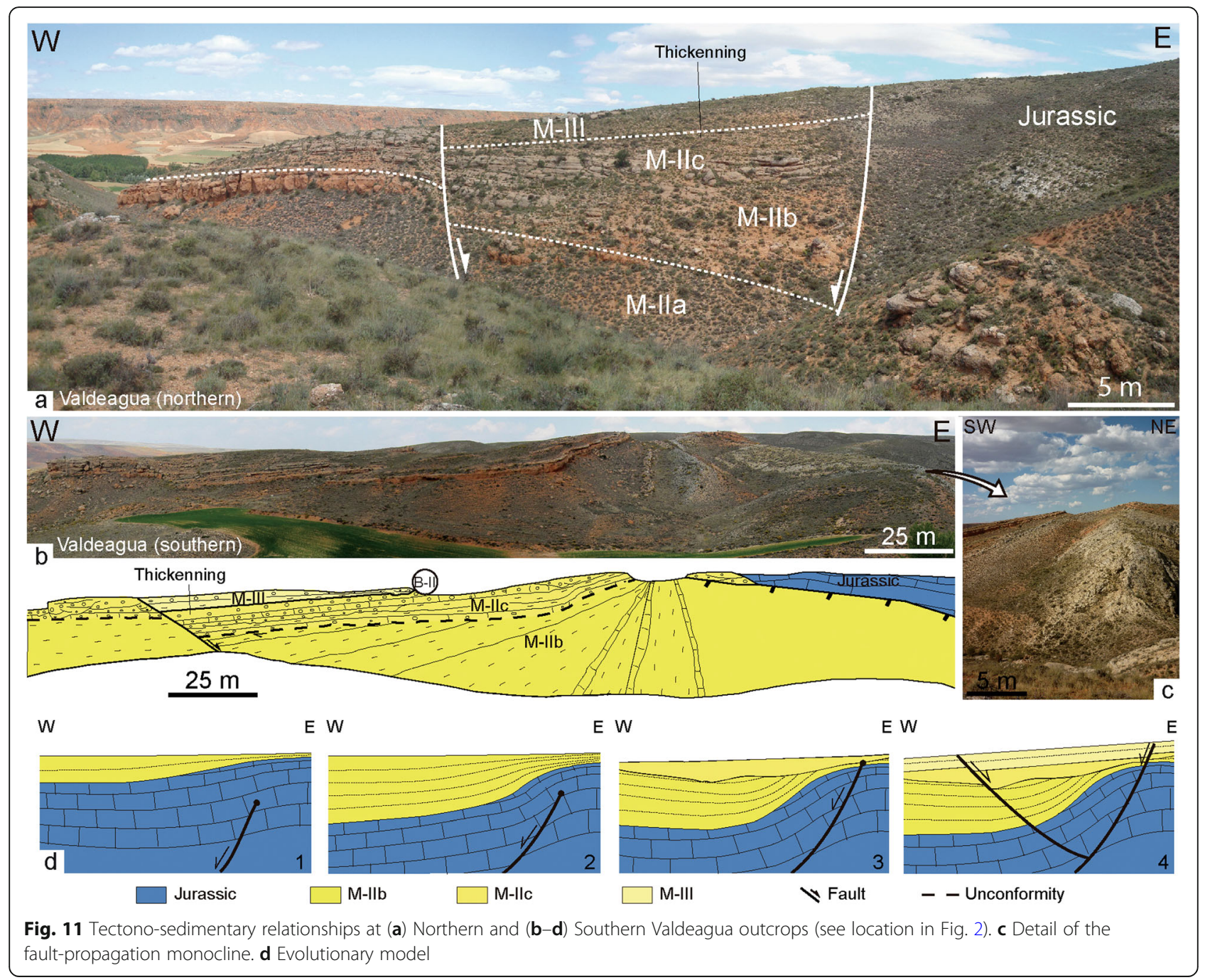

SSE trending Valdeagua and Galindo fault segments; (2) calcrete genesis (correlative of M-IIa) on Jurassic units, indicating a wide time-lapse of non-sedimentation; (3) activation of the NNE-SSW, both synthetic and antithetic growth faults that define this structural segment and sedimentation of $\mathrm{M}$-IIb related to a NW-directed VSAF filling the so-created space; the M-IIc evinces the maximum progradation and buries these faults; (4) deposition of retrograding M-III and extensional deformation probably located on the eastern major NNESSW fault, with associated drag folding.

Las Cabanillas segment This segment (Fig. 5) shows a structural and sedimentary framework similar to the Cuevas Ahumadas one. The main features at Las Cabanillas outcrop are: (i) development of an up to $1.8 \mathrm{~m}$ thick calcrete correlative to M-IIa forming a low-angle uncorformity with Jurassic limestones and initiation of deposition of M-IIb; (ii) tilting $\left(7-16^{\circ} \mathrm{NW}\right)$ of Pliocene and Jurassic beds; (iii) NNE-SSW striking faults offsetting Jurassic, M-IIa and lower part of M-IIb rocks; (iv) activation of the master fault that puts in contact Jurassic-Pliocene and Triassic rocks, (v) deposition of the prograding M-IIc megasequence overlaying previous deposits and faults; (vi) deposition of fining-upwards MIII indicating subsequent retrogradation. Las Cabanillas segment has been interpreted, similarly to the Cuevas Ahumadas one, as a relay ramp with associated VSAF sedimentation, which underwent subsequent linkage by transverse, NNE-SSW faults during M-IIb deposition.

\subsection{Tectono-stratigraphic evolution of the active margin}

Based on the formerly summarized tectono-sedimentary features, the following four-stage evolutionary model for the eastern active margin of the northern Teruel Basin is proposed (Fig. 13):

Stage 1 After M-I deposition, NNW-SSE strike faults were reactivated defining three structural segments (Valdeagua, Barranco Galindo, and El Vadillo). Dranaige 

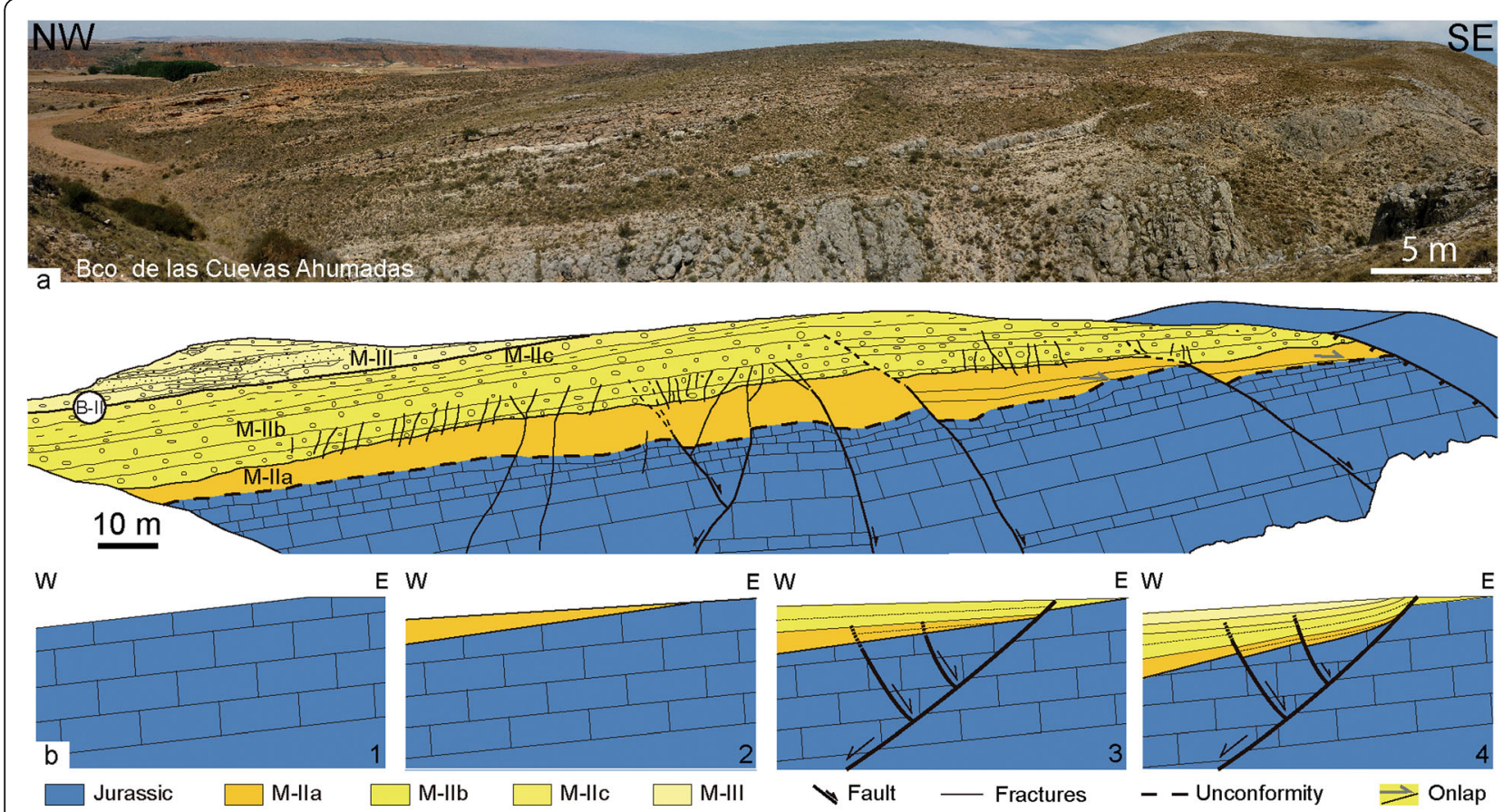

Fig. 12 a Panoramic field view and line drawing of tectono-sedimentary relationships at the Cuevas Ahumadas outcrop, within the NNE-SSW trending Cuevas Ahumadas segment (see location in Fig. 2); b Evolutionary model

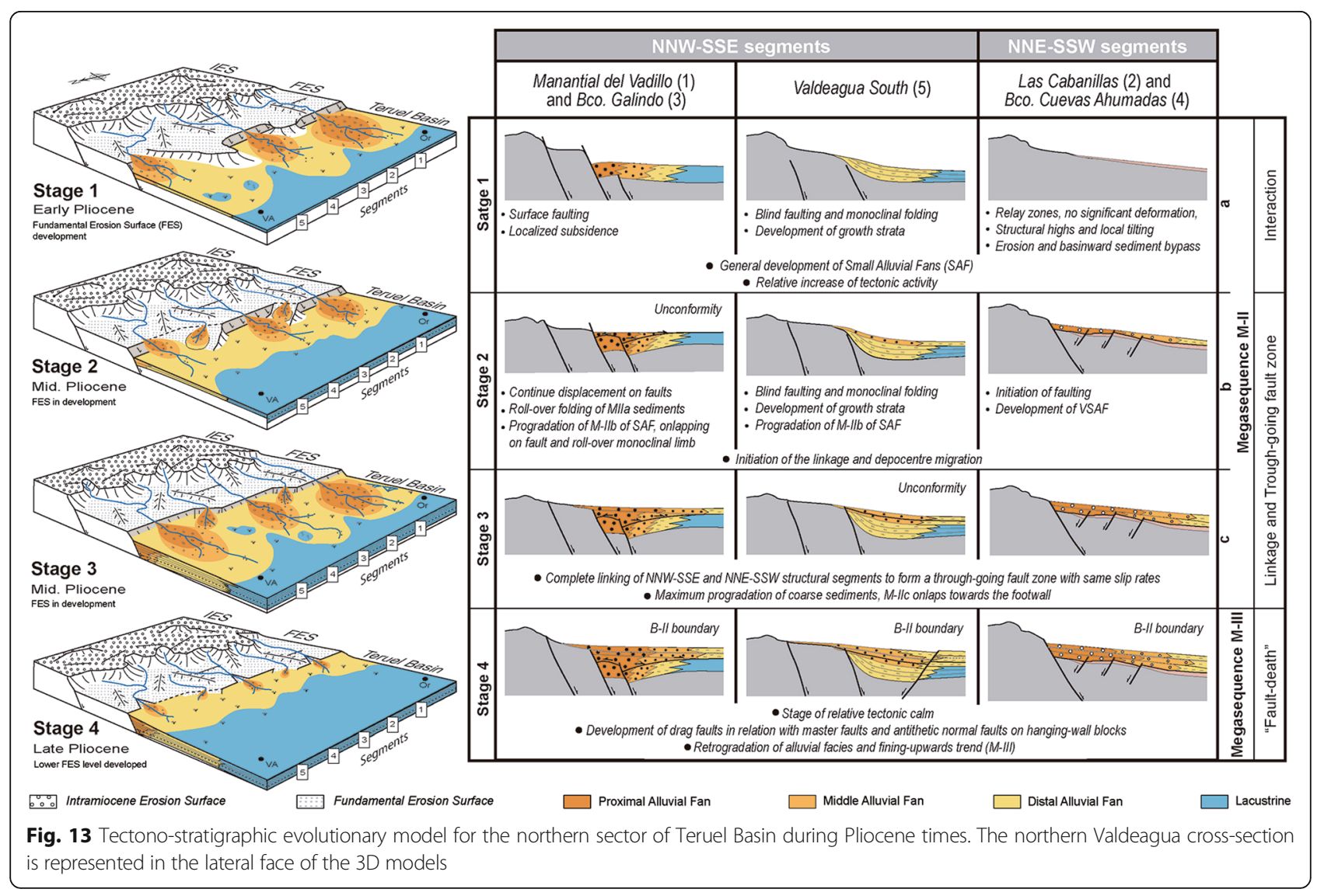


in the footwall catchment area (El Pobo Range) was probably diverted towards the east (El Pobo Basin), but some small alluvial fans (SAF) sourced in the rejuvenated relief spreaded westwards into the Teruel Basin. This stage approximately correlates with sedimentation of M-IIa and correlative calcrete genesis. In each individual fault, displacement and subsidence rate varied along strike: their central sectors usually showing surface break and higher displacement, while the southern Valdeagua segment, and beyond the fault tips in the other NNWSSE segments, faults remained as blind structures that induced gentle monoclines and growth-strata (Fig. 13). During this stage, the NNE-SSW segments remained virtually inactive, probably representing gentle relay ramps acting as sediment bypass areas or calcrete development.

Stage 2 NNE-SSW trending segments cutting previously tilted rocks at relay ramps were activated (Fig. 13). Northwest-directed very small alluvial fans (VSAF) spreaded from these segments; alluvial deposits covered in onlap towards SSE Pliocene calcretes and then Mesozoic rocks. Meanwhile, the NNW-SSE segments underwent significant displacement, with rollover folding deforming M-IIa (except in the southern Valdeagua segment, where the blind fault style continued). Increasing accommodation space was progressively filled with thickenned SAF deposits that belong to M-IIb, which onlapped both the master faults (buttress unconformity) and the limbs of rollover anticlines (onlap unconformity). The result is the here called onlap-over-rollover geometry (Fig. 14).

Stage 3 Linking of NNW-SSE and NNE-SSW structural segments was accomplished, and the resulting throughgoing fault zone acted as a single structure from the kinematical point of view during lower M-IIb (Fig. 13). Slip on this fault zone deposition led to overall sinking of the basin and displacement of subsiding areas basinwards. This change in basin setting coincides with widespread progradation of both types of alluvial fans (SAF and VSAF), which coalesced basinwards during M-IIc deposition.

Stage 4 Attenuation of fault displacement and relief degradation induced alluvial fan retrogradation during deposition of M-III, which ended with the final development of a regional erosional surface, the FES.

\section{Discussion}

\subsection{Megasequences and strata stacking patterns}

The megasequence $\mathrm{M}$-I records an alluvial retrograding pattern, which ended with the maximum lacustrine expansion taking place in the Teruel Basin during the middle Ruscinian (Ezquerro 2017). Alluvial retrogradation and extensive and homogeneous carbonate sedimentation has been interpreted as a result of sediment supply decrease associated to a quiescent tectonic period. The generally coarsening-upward megasequence MII was deposited during a subsequent, Late Ruscinian, tectonically active stage, as different stacking patterns and many deformation structures demonstrate. On the basis of the existence of local angular unconformities, the M-II megasequence has been subdivided into M-IIa, M-IIb, and M-IIc. Isolated troughs created by local fault development contain very different stratigraphical patterns, as common in rift basins (Lambiase and Bosworth 1995). The stratigraphic architecture was controlled by the tectonic setting, particularly by changes in accommodation space related to local subsidence and sediment supply (Gawthorpe et al. 1994; Withjack et al. 2002). In

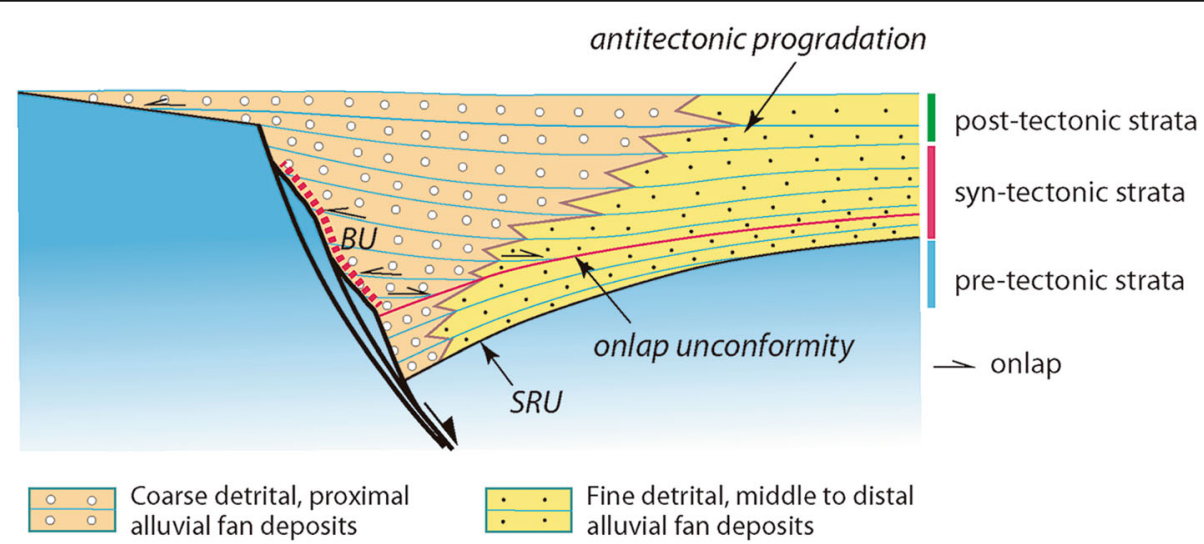

Fig. 14 Conceptual model of the onlap-over-rollover geometry described in this work, with growth strata associated to listrict normal faults revealing competition between tectonic subsidence and sedimentary supply rates. Synrift deposits are trapped and thickened close to the master fault and beds onlap both the master fault and the limb of the associated rollover anticline. In a subsequent scenario of decreasing tectonic activity, local subsident troughs are completely filled and, finally, a general widespread progradation of alluvial fans (i.e. antitetic progradation in the sense of Paola et al. 1992) is expected to occur. BU-Buttress unconformity; SRU-Syn-rift unconformity 
general, alluvial fans derived from the footwall were attached to the border faults and, as previously stated, were small in size because sediment supply from the footwall scarp drainage basins was not high (Gawthorpe and Colella 1990).

Differences in tectono-sedimentary features and strata stacking patterns are found, both between NNW-SSE and NNE-SSW trending segments and along each individual segment. Within the longer, NNW-SSE segments, a change of deformation style is observed between central parts, fault tips and areas beyond the tips. In central parts larger displacements and usually surficial rupture with an associated rollover (i.e., antithetic) monocline occur. The so created synsedimentary accommodation space favored the genesis of footwall-sourced small alluvial fans and thickenned successions (Withjack et al. 2002). Towards the fault tips, deformation decreased and growth-strata developed, as in the case of the Valdeagua Fault (Fig. 12). Beyond the fault tips the rupture did not reach the surface, and a synthetic bending monocline was formed above the blind fault. These patterns have been recognized in similar tectonic settings by e.g., Leeder and Gawthorpe (1987), Jackson and Leeder (1994), Gawthorpe and Leeder (2000) Willsey et al. (2002) and Jackson et al. (2006a). The described features evince high fault activity during M-II deposition that resulted in the creation of synformal troughs where significant thickness of syntectonic deposits were trapped, drawing a particular geometry that we name onlap-overrollover (Fig. 14). A scenario of high subsidence/sedimentary supply rate avoided widespread alluvial progradation basinwards, especially during M-IIb.

The final linkage of NNW-SSE and NNE-SSW structural segments is interpreted to have occurred during deposition of M-IIc. The through-going fault zone behaved as a single structure from the kinematic point of view and subsiding areas were displaced towards more central parts of the basin, in agreement with rebuilding of the basin margin due to complete fault linkage. The normally conformable M-IIc buried most border faults, evincing a decrease in the subsidence/sedimentary supply rate close to the margin, with local subsident troughs being completely filled and general widespread progradation of alluvial fans. This situation could have occurred either in a still active tectonic setting (with increasing sediment supply from the margin) or in a scenario of decreasing tectonic activity. In the later case the term antitectonic progradation (e.g., Paola et al. 1992) could be applied.

Finally, the transition to the undeformed finingupwards M-III, is attributed to an alluvial retrogradation during an episode of general decrease in sedimentary supply and decreasing tectonic activity in the whole basin, which ended with basin colmatation and development of a correlative, regional erosional surface, the
Fundamental Erosional Surface (FES). After FES development, a second major rifting stage took place in the region (Simón 1982, 1986), with an estimated throw of $460-520 \mathrm{~m}$ of the FES marker associated to the El Pobo Fault Zone (Liesa et al. 2019a). Because of further erosion, correlative sediments (coarsing-upwards M-IV) do not crop out close to eastern active faults, so that no direct relationship with them can be established. In any case, a joint movement of the overall fault zone should be expected.

\subsection{Controls on margin structure and evolution: structural inheritance and stress systems}

A zigzag fault zone can result from different genetic processes. Firstly, it can arise from an en-échelon fault array attaining full linkage by means of oblique, secondary faults cutting through relay zones (e.g., $\mathrm{R}$ and $\mathrm{P}$ fractures, in the case of strike-slip fault zones; Tchalenko 1970). Evolution of relay zones in homogeneous and isotropic materials tend to follow its own kinematic rules, essentially controlled by the relationship between geometry, transport direction and interaction of master faults (e.g., Cartwrigth et al. 1995; Gupta and Scholz 2000). Secondly, zigzag fault arrays are frequently controlled by inherited structures and their response to stress. Under the remote stress field, previous faults are selectively activated among the available crustal discontinuities; those favourably oriented can facilitate hard linkage of initially developed fault segments within a fault zone.

In the zigzag active margin of the northern Teruel Basin, this second scenario seems to be more likely. On one hand, the orientation of faults that control the alternating NNE-SSW and NNW-SSE trending segments approach the main directions of large-scale faults $(\mathrm{L}>2 \mathrm{~km})$ cutting Mesozoic rocks of the El Pobo footwall block (Liesa 2011b; Ezquerro 2017) (Fig. 8c), and similar faults, in strike and length, have been also mapped in the Mesozoic outcrops (Fig. 8a). In addition, in this sector of the Iberian Chain there are good examples of NNW-SSE trending, subvertical larger faults $(>20 \mathrm{~km})$ strongly controlling sedimentation and basin configuration during the Early Cretaceous rifting (Liesa et al. 2004, 2006; Liesa et al. 2018; Liesa 2011b; Navarrete et al. 2013; Aurell et al. 2016), as well as compressional structures during the early Cenozoic inversion (Liesa and Simón 2004; Liesa et al. 2004, 2019b; Simón-Porcar et al. 2019). These arguments strongly suggest that geometry and evolution of this margin was mainly controlled by inherited faults (see also Liesa et al. 2019a), so that the described shallow ruptures probably represent splay faults rooted at a major inherited, $\mathrm{N}-\mathrm{S}$ striking crust-scale fault.

On the other hand, NNE-SSW and NNW-SSE trending segments are nearly orthogonal to the main E-W (086-089) $\sigma_{3}$ direction of the near-radial extension 
regime, inferred from fault population analysis in syntectonic Pliocene deposits. In addition, the prevailing N-S to NNW-SSE fracture pattern in Pliocene deposits (more simple than that described for the Mesozoic) likely reveals the true imprint of the Late Neogene, E-W extensional stress field in opposition to the Mesozoic inheritance. The described Pliocene regional stress system $\left(\sigma_{3}\right.$ direction and regime) in the region is intermediate between those characterizing the two Neogene rift episodes affecting central-eastern Iberian Chain, firstly triaxial extension with $\sigma_{3} \mathrm{E}-\mathrm{W}$ and, from close to the Ruscinian-Villafranchian boundary, almost 'radial' extension $\left(\sigma_{1}\right.$ vertical, $\left.\sigma_{2} \approx \sigma_{3}\right)$ with a prevailing $\sigma_{3}$ ENEWSW (Simón 1986, 1989; Herraiz et al. 2000; Arlegui et al. 2005, 2006; Liesa et al. 2019a). The intermediate features developed during the Pliocene fit well the transition between both extensional stress fields, and they allow improvement of the characterization of such a transition period. Thus, a gradual change towards an almost radial extension should have occurred, $\sigma_{3}$ trajectories first remaining close to E-W (086-089) and then turning to the prevailing ENE-WSW direction during the Quaternary.

Our interpretation is that NNW-SSE striking faults were activated by middle Pliocene times, under the E-W trending $\sigma_{3}$ trajectories. Subsequently, during the Late Pliocene, activation of NNE-SSW structures allowed three-dimensional, bulk deformation associated to E-W extension to be accommodated, therefore resulting in a zigzag extensional margin that somewhat constitutes an orthorombic or 'biconjugate' fault system (Reches 1978; Reches and Dieterich 1983). In such context, local perturbation related to interaction between NNW-SSE neighbouring normal faults, as it occurs in nature and mathematical and experimental models (e.g., Simón et al. 1988, 1999), could have favoured slight change of stress directions, the $\sigma_{3}$ axis locally switching to ESEWNW and thus triggering activation of NNE-SSW faults in the previous relay zone. In summary, such evolutionary model does not strictly represent two successive tectonic phases, but 'time dissociation' of the extensional stress field into two stress systems, i.e. a case of stress partitioning as defined by Simón et al. (2008).

Similar sequential faulting processes giving rise to zigzag basin margins have been described within the East African rift system, also related to changes in stress systems either in time (e.g., Malawi Rift; Mortimer et al. 2007, 2016) or space (arcuate western branch, Tanganika-Albert; Lezzar et al. 2002; Corti et al. 2007). Changes in extension direction led to episodes of oblique rifting, in which NE-SW or NW-SE striking faults connecting the master, N-S striking border faults were activated. Nevertheless, oblique rifting in East Africa probably occurred under stress conditions of relatively high horizontal deviatoric stress $\left(\sigma_{2}-\sigma_{3}\right)$, resulting in local transtension (Lezzar et al. 2002; Mortimer et al. 2007). In contrast, the biaxial or 'multidirectional' extensional regime prevailing in the eastern Iberian Chain since the Pliocene allowed each single structure within the zigzag array to be activated as a nearly pure dip-slip normal fault.

\subsection{Differences from previous models: margin width and alluvial fan size}

The proposed tectono-stratigraphic model is consistent with results of both previos studies of zigzag extensional margins and experimental models that involve growth, propagation and linkage of different en-échelon normal faults (e.g., Cartwright et al. 1995, Willemse et al. 1996, Crider and Pollard 1998, Walsh et al. 1999, Gupta and Scholz 2000), always assuming a scenario in which inherited structures play an essential role in tectono-stratigraphic evolution (Trudgill and Cartwright 1994; Trudgill 2002). Nevertheless, some differences should be pointed out.

Previous models usually suggest that vertical movement and tilting associated with normal faults induce drainage patterns strongly influenced by fault length. Large alluvial fans are located between fault segments (i.e. at relay zones), since drainage basins in the footwall hinterlands are usually much larger than those directly set up at the border faults. These features have been observed in margins of large extensional basins such as Basin and Range (e.g., Leeder and Jackson 1993; Jackson and Leeder 1994; Densmore et al. 2004) or Gulf of Suez (e.g., Jackson et al. 2002, 2006b; Moustafa 2002), where length of structures (as well as spacing between them) is of the order of tens of kilometers, and the catchment headwaters are located far from the active margin.

In the Teruel Basin, the size of the different segments permits the El Pobo Fault Zone to be essentially considered as an en-échelon arrangement of NNW-SSE trending faults, separated by right-stepping relay zones that correspond to the shorter NNE-SSW segments. Interestingly, alluvial fans in the relay zones are smaller than those adjacent to the long fault segments, as can be clearly observed e.g., in the Orrios-Villalba Alta area. This needs to be explained in the light of the tectonic and geomorphological framework of the studied area. Unlike basin margins on which the previous models are based, the active margin of the northern Teruel Basin is quite narrow. The proximity between successive fault segments would therefore favour the catchment areas in each footwall block to have been strongly constrained, due to interference between nearby drainage systems and subsequent capture processes. Moreover, the small size of relay zones, only a few hundred meters wide, diminished the probability that they coincide with the outlets of hypothetical large drainage basins on the El 
Pobo Range, thus avoiding development of large alluvial fans. On the other hand, the proximity between the fault traces facilitated the connection of fault segments in a single basin margin, thus resulting in early linkage (Gupta et al. 1999; Moustafa 1997, 2002). Keeping of stable relay ramps was inhibited as the transition from isolated segments to linkage stage occurred in less than $0.3 \mathrm{Ma}$. Accordingly, alluvial fans in the relay ramps did not have enough time for developing.

Geomorphological control of alluvial fans mainly concerns the position and evolution of drainage systems towards the Teruel Basin. It is known that tilting accompanying footwall uplift tends to produce surfaces that slope and drain away from the associated basin, so that drainage systems sourced at the footwall blocks supply limited sediment to the rift basin (Withjack et al. 2002). The watershed reconstructed from the present-day remnants of the Intramiocene Erosion Surface on the top of El Pobo Range has been located very close to the basin since Late Miocene times (Fig. 6); such situation would have avoided the development of large catchment areas draining towards the Teruel Basin, since most of the footwall block drainage (El Pobo Range) diverted eastwards, towards the El Pobo Basin (Simón-Porcar et al. 2018, 2019), due to tectonic tilting. Accordingly, the Teruel Basin only received sediments coming from the mountain front. Hard lithology of the source area (dominated by Mesozoic limestones) also avoided the development of large drainage basins, as has been also noted by Gawthorpe et al. (1994).

\section{Conclusions}

1) The eastern active margin of the northern Neogene Teruel Basin is made of a dense network of NNESSW and NNW-SSE faults that are derived from the main sets of inherited Mesozoic fractures. The margin evolution was characterised by a selective reactivation of previous faults under a favorably orientated stress field ( $\sigma_{3}$ close to E-W), a process easier than the formation of new faults directly controlled by the remote stress field or the kinematics of the fault zone. The final result was early linkage of faults through narrow relay zones that enabled prompt development of a zigzag margin.

2) The drainage pattern and sedimentary evolution seem to have been strongly controlled by the dense structural anisotropy inherited from previous stages, since it carefully regulated: (i) the width of the active margin, (ii) a shorter size of the relay zones in relation to the en-échelon normal faults, and (iii) the rate of fault propagation. In addition, the general tilting of the footwall block during deformation and the drainage divide on the footwall block, located very close to the basin, also played an important role, inhibiting development of large catchment areas draining towards the basin. Narrow catchment areas in the mountain front, also favored by a high fault density, sourced small alluvial fans spreading towards the Teruel Basin. During the first stages activity in relatively short $(<2 \mathrm{~km})$ NNW-SSE faults favored development of small alluvial fans (up to $5 \mathrm{~km}$ long), acting the NNW-SSE segments as relay ramps. Later on such segments also progressively activated, and NW-directed very small alluvial fans (less than $1 \mathrm{~km}$ long) were generated. This setting contrasts with previous models described at large rift basins (e.g., Basin and Range or Gulf of Suez), where wide catchment areas installed on the basin margins drain through wide fault relay zones sourcing large alluvial fans, while small alluvial fans are sourced from fault scarps.

3) Tectono-stratigraphic evolution was highly controlled by changes in the subsidence/sedimentary supply ratio. Local unconformities, and certain specific strata stacking patterns (onlap-over-rollover and growthstrata), evince a high fault activity during Ruscinian times. Faults with larger displacement and surficial rupture (i.e. at their central portions) induced formation of associated rollover (i.e. antithetic) monoclines and synformal troughs that were progressively filled with syntectonic deposits with onlap-over-rollover geometries. Towards the fault tips, displacement decreased and growth-strata developed which were linked to bending monoclines originated above blind synthetic faults. After achievement of fault linkage and maximum fault displacement, basinwards alluvial progradation only occurred once the troughs were filled and the border faults were buried.

\section{Abbreviations}

FES: Funfamental Erosion Surface; IES: Intramiocene Erosion Surface; SAF: Small Alluvial Fans; VSAF: Very Small Alluvial Fans

\section{Acknowledgements}

We would thank Yuan Wang and two anonymous reviewers for their valuable comments and suggestions which have permitted to improve the final version of our manuscript. The research has been financed by project CGL2012-35662 of Spanish Ministerio de Economía y Competitividad-FEDER. This work is a contribution of the Geotransfer research group (E32_17R), co-financed by the Aragón Government and the PO FEDER-Aragón 2014-2020.

\section{Authors' contributions}

Interpretations, analysis, discussion and conclusions have been done by all authors. All of them read and approved the final manuscript.

\section{Funding}

This project was supported by project number CGL2012-35662 of Spanish Ministerio de Economía y Competitividad-FEDER. and co-financed by the Aragón Government and the PO FEDER-Aragón 2014-2020.

\section{Availability of data and materials}

All data generated or analysed during this study are included in this published article [and its supplementary information files]. 


\section{Competing interests}

The authors declare that they have no competing interests.

Received: 12 February 2019 Accepted: 5 September 2019

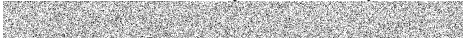

\section{References}

Adrover, R. 1986. Nuevas faunas de roedores en el Mio-Plioceno continental de la región de Teruel (España), Interés bioestratigráfico y paleoecológico, 423. Teruel: Instituto de Estudios Turolenses.

Agustí, J., L. Cabrera, M. Garcés, W. Krijgsman, O. Oms, and J.M. Parés. 2001. A calibrated mammal scale for the Neogene of Western Europe. State of the art. Earth-Science Reviews 52: 247-260.

Alcalá, L., A.M. Alonso-Zarza, M.A. Álvarez, B. Azanza, J.P. Calvo, J.C. Cañaveras, J.A. van Dam, M. Garcés, W. Krijgsman, A.J. van der Meulen, J. Morales, P. Peláez, A. Pérez-González, S. Sánchez, R. Sancho, and E. Sanz. 2000. El registro sedimentario y faunístico de las cuencas de CalatayudDaroca y Teruel. Evolución paleoambiental y paleoclimática durante el Neógeno. Revista de la Sociedad Geológica de España 13: 323-343.

Alonso-Zarza, A.M. 2003. Palaeoenvironmental significance of palustrine carbonates and calcretes in the geological record. Earth-Science Reviews 60: $261-298$

Alonso-Zarza, A.M., V.P. Wright, J.P. Calvo, and M.A. García del Cura. 1992. Soil landscape and climatic relationships in the middle Miocene of the Madrid Basin. Sedimentology 39: 17-35.

Álvaro, M., R. Capote, and R. Vegas. 1979. Un modelo de evolución geotectónica para la Cadena Celtibérica. Acta Geológica Hispánica 14: 172-177.

Arlegui, L.E., J.L. Simón, R.J. Lisle, and T. Orife. 2005. Late PliocenePleistocene stress field in the Teruel and Jiloca grabens (eastern Spain): Contribution of a new method of stress inversion. Journal of Structural Geology 27: 693-705.

Arlegui, L.E., J.L. Simón, R.J. Lisle, and T. Orife. 2006. Analysis of non-striated faults in a recent extensional setting: The Plio-Pleistocene Concud fault (Jiloca graben, eastern Spain). Journal of Structural Geology 28: 1019-1027.

Aurell, M., B. Bádenas, J.M. Gasca, I. Canudo, C.L. Liesa, A.R. Soria, M. MorenoAzanza, and L. Najes. 2016. Stratigraphy and evolution of the Galve subbasin (Spain) in the middle Tithonian-early Barremian: Implications for the setting and age of some dinosaur fossil sites. Cretaceous Research 65: $138-162$

Belenguer Oliver, J., E. Roca Abella, and O. Gratacós Torrá. 2012. Evidencias de una rampa de relevo extensivo de edad miocena en el sector del Baix Llobregat de la falla del Vallès-Penedès, Cataluña. In Geo-Temas 13: Resúmenes extendidos del VIII Congreso Geológico de España, ed. L.P. Fernández, A. Fernández, A. Cuesta, and J.R. Bahamonde, 141-144.

Bott, M.H.P. 1959. The mechanics of oblique slip faulting. Geological Magazine 96: 109-117.

Bull, W.B. 1972. Recognition of alluvial fan deposits in the stratigraphic record. In Recognition of ancient sedimentary environments, SEPM special publication, ed. J.K. Rigby and W.K. Hamblin, vol. 16, 63-83.

Capote, R., J.A. Muñoz, J.L. Simón, C.L. Liesa, and L.E. Arlegui. 2002. Alpine tectonics I: The Alpine system north of the Betic cordillera. In Geology of Spain, ed. W. Gibbons and T. Moreno, 367-400. The Geological Society of London.

Carroll, A.R., and K.M. Bohacs. 1999. Stratigraphic classification of ancient lakes: Balancing tectonic and climatic controls. Geology 27: 99-102.

Cartwrigth, J.A., B.D. Trudgill, and C.S. Mansfield. 1995. Fault growth by segment linkage: An explanation for scatter in maximum displacement and trace length data from the Canyonlands graben of S.E. Utah. Journal of Structural Geology 17: 1319-1326.

Catuneanu, O., J.P. Bhattacharya, M.D. Blum, R.W. Dalrymple, P.G. Eriksson, C.R. Fielding, W.L. Fisher, W.E. Galloway, P. Gianolla, M.R. Gibling, K.A. Giles, J.M. Holbrook, R. Jordan, C.G.St.C. Kendall, B. Macurda, O.J. Martinsen, A.D. Miall, D. Nummedal, H.W. Posamentier, B.R. Pratt, K.W. Shanley, RJ. Steel, A. Strasser, and M.E. Tucker. 2011. Sequence stratigraphy: Common ground after three decades of development. First Break 28: 21-34.

Contreras, J., C.H. Scholz, and G.C.P. King. 1997. A model of rift basin evolution constrained by first-order stratigraphic observations. Journal of Geophysical Research 102: 7673-7690.
Corti, G., J. van Wijk, S. Cloething, and C.K. Morley. 2007. Tectonic inheritance and continental rift architecture: Numerical and analogue models of the east African Ryft system. Tectonics 26: TC6006. https://doi. org/10.1029/2006TC002086.

Crider, J.G., and D.D. Pollard. 1998. Fault linkage: Three dimensional mechanical interaction between echelon normal faults. Journal of Geophysical Research 103: 24373-24391.

Dasgupta, P. 2003. Sediment gravity flow-the conceptual problems. EarthScience Reviews 62: 265-281.

Dawers, N.H., and J.R. Underhill. 2000. The role of fault interaction and linkage in controlling syn-rift stratigraphic sequences: Statfjord east area, northern North Sea. AAPG Bulletin 84: 45-64.

Densmore, A.L., N.H. Dawers, S. Gupta, R. Guidon, and T. Goldin. 2004. Footwall topographic development during continental extension. Journal of Geophysical Research 109: F03001. https://doi.org/10.1029/2003JF000115.

Etchecopar, A., G. Vasseur, and M. Daignières. 1981. An inverse problem in microtectonics for the determination of stress tensors from fault striation analysis. Journal of Structural Geology 3: 51-65.

Ezquerro, L. 2017. El sector norte de la cuenca neógena de Teruel: tectónica, clima y sedimentación. Vol. 496. Zaragoza: Universidad de Zaragoza http://zaguan.unizar.es/record/77098\#.

Ezquerro, L., P. Lafuente, Ma.D. Pesquero, L. Alcalá, L.E. Arlegui, C.L. Liesa, L. Luque, M.A. Rodríguez-Pascua, and J.L. Simón. 2012b. Una cubeta endorreica residual plio-pleistocena en la zona de relevo entre las fallas de Concud y Teruel: implicaciones paleogeográficas. Revista de la Sociedad Geológica de España 25: 157-175.

Ezquerro, L., A. Luzón, M. Navarro, C.L. Liesa, and J.L. Simón. 2014. Climatic vs. tectonic signals in a continental extensional basin (Teruel, NE Spain) from stable isotope $\left(\delta^{18} \mathrm{O}\right)$ and sequence stratigraphical evolution. Terra Nova 26: 337-346

Ezquerro, L., M.A. Luzón, C.L. Liesa, and J.L. Simón. 2012a. Evolución megasecuencial del relleno mio-plioceno del sector norte de la cuenca de Teruel: interacciones entre tectónica y sedimentación. In Geo-Temas 13: Resúmenes extendidos del VIII Congreso Geológico de España, ed. L.P. Fernández, A. Fernández, A. Cuesta, and J.R. Bahamonde, 171-174.

Ezquerro, L., M. Moretti, C.L. Liesa, A. Luzón, E.L. Pueyo, and J.L. Simón. 2016. Controls on space-time distribution of soft-sediment deformation structures: Approaching the apparent recurrence period of paleoseisms at the Concud fault (eastern Spain). Sedimentary Geology 344: 91-111.

Galloway, W.E., and D.K. Hobday. 1983. Terrigeneous clastic depositional systems, 489. Berlin: Springer-Verlag.

Gawthorpe, R.L., and A. Colella. 1990. Tectonic controls on coarse-grained delta depositional systems in rift basins. In Coarse-grained Deltas, Special Publication International Association Sedimentologists, ed. A. Colella and D. Prior, vol. 10, 113-120.

Gawthorpe, R.L., R.E.L. Collier, and A.J. Fraser. 1994. Sequence stratigraphy in active extensional basins: Implications for the interpretation of ancient basin fills. Marine and Petroleum Geology 11: 642-658.

Gawthorpe, R.L., S. Hardy, and B. Ritchie. 2003a. Numerical modelling of depositional sequences in half-graben rift basins. Sedimentology 50: 169-185.

Gawthorpe, R.L., and J.M. Hurst. 1993. Transfer zones in extensional basins: Their style and influence on drainage development and stratigraphy. Journal of the Geological Society of London 150: 1137-1152.

Gawthorpe, R.L., C.A.L. Jackson, M.J. Young, I.R. Sharp, A.R. Moustafa, and C. W. Leppard. 2003b. Normal fault growth, displacement localisation and the evolution of normal fault populations: The Hammam Faraun fault block, Suez rift, Egypt. Journal of Structural Geology 25: 883-895.

Gawthorpe, R.L., and M.R. Leeder. 2000. Tectono-sedimentary evolution of active extensional basins. Basin Research 12: 195-218.

Gawthorpe, R.L., I.R. Sharp, J.R. Underhill, and S. Gupta. 1997. Linked sequence stratigraphic and structural evolution of propagating normal faults. Geology 25: 795-798

Gierlowski-Kordesch, E. 2010. Lacustrine carbonates. In Carbonates in sedimentary settings. Facies, environments and processes, ed. A.M. Alonso-Zarza and L.H. Tarnner, vol. 1, 1-70. Cambridge: Cambridge University Press.

Godoy, A., E. Moissenet, J.I. Ramírez, A. Olivé, J.M. Aznar, L. Jérez Mir, E. Aragonés, M.J. Aguilar, J. Ramérez Del Pozo, M.C. Leal, R. Adrover, M.T. 
Alberdi, J. Giner, M. Gutiérrez Elorza, J.M. Portero, and V. Gabaldón. 1983. Mapa Geológico de España 1:50.000, hoja n 542 (Alfambra). Madrid: IGME.

Guimerà, J., and M. Álvaro. 1990. Structure et evolution de la compression alpine dans la Chaine Cotiere Catalane (Espagne). Bulletin of Societe Géologique of France 8: 339-348.

Gupta, S., and C.H. Scholz. 2000. A model of normal fault interaction based on observations and theory. Journal of Structural Geology 22: 865-880.

Gupta, S., J.R. Underhill, I.R. Sharp, and R.L. Gawthorpe. 1999. Role of fault interactions in controlling synrift sediment dispersal patterns: Miocene, Abu Alaqa group, Suez rift, Sinai, Egypt. Basin Research 11: 167-189.

Gutiérrez, F., M. Gutiérrez, F.J. Gracia, J.P. McCalpin, P. Lucha, and J. Guerrero. 2008. Plio-quaternary extensional seismotectonics and drainage network development in the central sector of the Iberian range (NE Spain). Geomorphology 102: 21-42.

Gutiérrez, M., and F.J. Gracia. 1997. Environmental interpretation and evolution of the tertiary erosion surfaces in the Iberian range (Spain). In Palaeosurfaces: Recognition, Reconstruction and Palaeoenvironmental Interpretation, Geological Society Special Publication, ed. M. Widdowson, vol. 120, 147-158.

Gutiérrez, M., and J.L. Peña. 1976. Glacis y terrazas en el curso medio del río Alfambra (provincia de Teruel). Boletín Geológico y Minero 87: 561-570.

Hampton, M.A. 1979. Buoyancy in debris flows. Journal of Sedimentary Petrology 49: 753-758.

Hein, F.J., and R.G. Walker. 1977. Bar evolution and development of stratification in the gravelly, braided, kicking Horse River, British Columbia. Canadian Journal of Earth Sciences 14: 562-570.

Herraiz, M., G. De Vicente, R. Lindo, J. Giner, J.L. Simón, J.M. González, O. Vadillo, M.A. Rodríguez, J.l. Cicuéndez, A. Casas, P. Rincón, A.L. Cortés, and M. Lucini. 2000. The recent (Upper Miocene to quaternary) and present tectonics stress distributions in the Iberian Peninsula. Tectonics 19: 762-786.

Hus, R., V. Acocella, R. Funiciello, and M. De Batist. 2005. Sandbox models of relay ramp structure and evolution. Journal of Structural Geology 27: 459-473.

Jackson, C.A.-L., R.L. Gawthorpe, C.W. Leppard, and I.R. Sharp. 2006b. Riftinitiation development of normal fault blocks: Insights from the Hammam Faraun fault block, Suez rift, Egypt. Journal of the Geolological Society of London 163: 165-183.

Jackson, C.A.L., R.L. Gawthorpe, and I.R. Sharp. 2002. Growth and linkage of the east Tanka fault zone, Suez rift: Structural style and syn-rift stratigraphic response. Journal of the Geolological Society of London 159: 175-187.

Jackson, C.A.-L., R.L. Gawthorpe, and I.R. Sharp. 2006a. Style and sequence of deformation during extensional fault-propagation folding: Examples from the Hammam Faraun and El-Qaa fault blocks, Suez rift, Egypt. Journal of Structural Geology 28: 519-535.

Jackson, J.A., and M.R. Leeder. 1994. Drainage systems and the development of normal faults: An example from Pleasant Valley, Nevada. Journal of Structural Geology 16: 1041-1059.

Lambiase, J.J. 1990. A model for the tectonic control of lacustrine stratigraphic sequences in continental rift basins. In Lacustrine exploration: Case studies and modern analogues, ed. B.J. Katz. AAPG Memoir 50: 265-276.

Lambiase, J.., and W.P. Bosworth. 1995. Structural controls on sedimentation in continental rifts. In Hydrocarbon habitat in rift basins, ed. J.J. Lambiase, vol. 80, 117-144. London: Geological society special publication London.

Leeder, M.R., and R.L. Gawthorpe. 1987. Sedimentary models for extensional tilt-block/half-graben basins. In Continental extensional tectonics, ed. M.P. Coward, J.F. Dewey, and P.L. Hancock, vol. 28, 139-152. London: Geological society special publication.

Leeder, M.R., and J.A. Jackson. 1993. The interaction between normal faulting and drainage in active extensional basins, with examples from the western United States and Central Greece. Basin Research 5: 79-102.

Lezzar, K.E., J.-J. Tiercelin, C. Le Turdu, A.S. Cohen, D.J. Reynolds, B. Le Gall, and C.A. Scholz. 2002. Control of normal fault interaction on the distribution of major Neogene sedimentary depocenters, Lake Tanganyika, east African rift. AAPG Bulletin 86: 1027-1059.

Liesa, C.L. 2000. Fracturación y campos de esfuerzos compresivos alpinos en la Cordillera Ibérica y el NE peninsular. Unpublished PhD Thesis. Zaragoza: Universidad de Zaragoza.
Liesa, C.L. 2011a. Evolución de campos de esfuerzos en la Sierra del Pobo (Cordillera Ibérica, España). Revista de la Sociedad Geológica de España 24: 49-68.

Liesa, C.L. 2011 b. Fracturación extensional cretácica en la Sierra del Pobo (Cordillera Ibérica, España). Revista de la Sociedad Geológica de España 24: 31-48.

Liesa, C.L., A.M. Casas, and J.L. Simón. 2018. La tectónica de inversión en una región intraplaca: la Cordillera Ibérica. Revista de la Sociedad Geológica de España 31 (2) in press.

Liesa, C.L., A.M. Casas, A.R. Soria, J.L. Simón, and A. Meléndez. 2004. Estructura extensional cretácica e inversión terciaria en la región de Aliaga-Montalbán. Geo-Guías 1: 151-180

Liesa, C.L., J.P. Rodríguez-López, L. Ezquerro, P. Alfaro, M.A. Rodríguez-Pascua, P. Lafuente, L.E. Arlegui, and J.L. Simón. 2016. Facies control on seismites in an alluvial-aeolian system: The Pliocene dunefield of the Teruel halfgraben basin (eastern Spain). Sedimentary Geology 344: 237-252.

Liesa, C.L., and J.L. Simón. 2004. Modelos de inversión positiva en sistemas de fallas normales en graderío: los márgenes de las cuencas extensionales cretácicas en la Cordillera Ibérica centro-oriental. Geotemas 6: 229-232.

Liesa, C.L., and J.L. Simón. 2009. Evolution of intraplate stress fields under multiple compressions: The case of the Iberian chain (NE Spain). Tectonophysics 474: 144-159.

Liesa, C.L., J.L. Simón, L. Ezquerro, L.E. Arlegui, and A. Luzón. 2019a. Stress evolution and structural inheritance controlling an intracontinental extensional basin: The central-northern sector of the Neogene Terue Basin. Journal of Structural Geology 118: 362-376.

Liesa, C.L., A.R. Soria, A. Casas, M. Aurell, N. Meléndez, and B. Bádenas. 2019b. The late Jurassic-early cretaceous rifting stage at the central and eastern Iberian Basin: The central and eastern Iberian Basin. In: J. Quesada, and T. Oliveira (Ed.).Geology of Iberia: a Geodynamic Approach, Springer, 3, (5): 214-228.

Liesa, C.L., A.R. Soria, N. Meléndez, and A. Meléndez. 2006. Extensional fault control on the sedimentation patterns in a continental rift basin: El Castellar formation, Galve sub-basin, Spain. Journal of the Geological Society of London 163: 487-498.

Lisle, R.J., T. Orife, and L.E. Arlegui. 2001. A stress inversion method requiring only fault slip sense. Journal of Geophysical Research Solid Earth 106: 2281-2289.

Lowe, D.R. 1982. Sediment gravity flows; II. Depositional models with special reference to the deposits of high-density turbidity currents. Journal of Sedimentary Petrology 52: 279-297.

Luzón, A. 2005. Oligocene-Miocene alluvial sedimentation in the northern Ebro Basin, NE Spain: Tectonic control and palaeogeographical evolution. Sedimentary Geology 177: 19-39.

McClay, K.R., T. Dooley, P. Whitehouse, and M. Mills. 2002. 4-D evolution of rift systems: Insights from scaled physical models. AAPG Bulletin 86: 935-959.

McLane, M. 1995. Sedimentology, 423. New York: Oxford University Press.

Mein, P. 1975. Report on activity RCMNS-working groups (1971-1975), 78-81. Bratislava.

Mein, P., E. Moissenet, and R. Adrover. 1983. L'extension et l'age des formations continentales pliocenes du fossé de Teruel. Comptes Rendus de l'Academie des Sciences de Paris 296: 1603-1610.

Mein, P., E. Moissenet, and R. Adrover. 1990. Biostratigraphie du Néogène supérieur de Teruel. Paleontología i Evolució 23: 121-139.

Miall, A.D. 1978. Lithofacies types and vertical profile models in braided river deposits: A summary. In Fluvial sedimentology, Canadian Society of Petroleum Geology Memoir, ed. A.D. Miall, vol. 5, 1-47.

Miall, A.D. 1985. Architecture-element analysis: A new method of facies analysis applied to fluvial deposits. Earth-Science Reviews 22: 261-308.

Moissenet, E. 1980. Relief et deformations récentes trois transversales dans les fossés internes des chaînes Ibériques orientales. Reviste Géographique Pyrenées et Sud-Ouest 51: 315-344.

Moissenet, E. 1983. Aspectos de la Neotectónica en la fosa de Teruel. In Geología de España. Libro Jubilar J.M. Ríos, Vol. II, ed. J.A. Comba, 427446. Madrid: IGME.

Mortimer, EJ., D.A. Paton, C.A. Scholz, and M.R. Strecker. 2016. Implications of structural inheritance in oblique rift zones for basin compartmentalization: Nkhata basin, Malawi rift (EARS). Marine and Petroleum Geology 72: 110-121. 
Mortimer, EJ., D.A. Paton, C.A. Scholz, M.R. Strecker, and P. Blisniuk. 2007. Orthogonal to obloque rifting: Effect of rift basin orientation in the evolution of the North Basin, Malawi rift, East Africa. Basin Research 19: 393-407.

Moustafa, A.R. 1997. Controls on the geometry of transfer faults in the Suez rift and Red Sea: Implications for the structural geometry of the systems. AAPG Bulletin 86: 979-1002.

Moustafa, A.R. 2002. Controls on the development and evolution of transfer zones: The influence of basement structure and sedimentary thickness in the Suez rift and Red Sea. Journal of Structural Geology 19: 755-768.

Moustafa, A.R., and S.M. Khalii. 2017a. Control of extensional transfer zones on syntectonic and post-tectonic sedimentation: Implications for hydrocarbon exploration. Journal of the Geological Society of London 174: 318-335.

Moustafa, A.R., and S.M. Khalil. 2017b. Control of compressional transfer zones on syntectonic and post-tectonic sedimentation: Implications for hydrocarbon exploration. Journal of the Geological Society of London 174: 336-352.

Muñoz-Jiménez, A., and A.M. Casas-Sainz. 1997. The Rioja trough (N Spain): Tecto-sedimentary evolution of a symmetric foreland basin. Basin Research 9: 65-85.

Navarrete, R., J.P. Rodríguez-López, C.L. Liesa, A.R. Soria, and L.V. Fernanda de Mesquita. 2013. Changing physiography of rift basins as a control on the evolution of mixed siliciclastic-carbonate back-barrier systems (Barremian Iberian Basin, Spain). Sedimentary Geology 289: 40-61.

Opdyke, N., P. Mein, E. Lindsay, A. Pérez-González, E. Moissenet, and V.L. Norton. 1997. Continental deposits, magnetostratigraphy and vertebrate paleontology, late Neogene of eastern Spain. Palaeogeography, Palaeoclimatology, Palaeoecology 133: 129-148.

Paola, C., P.L. Heller, and C.L. Angevine. 1992. The large scale dynamics of grain-size variation in alluvial basins, 1: Theory. Basin Research 4: 73-90.

Pardo, G., J. Villena, and A. González. 1989. Contribución a los conceptos y a la aplicación del análisis tectosedimentario. Rupturas y unidades tectosedimentarias como fundamento de correlaciones estratigráficas. Revista de la Sociedad Geológica de España 2: 199-221.

Pascucci, V., A. Costantini, I.P. Martini, and R. Dringoli. 2006. Tectonosedimentary analysis of a complex, extensional, Neogene basin formed on thrust-faulted, northern Apennines hinterland: Radicofani Basin, Italy. Sedimentary Geology 183: 71-97.

Peacock, D.C.P., and D.J. Sanderson. 1991. Displacements, segment linkage and relay ramps in normal fault zones. Journal of Structural Geology 13: 721-733.

Peacock, D.C.P., and D.J. Sanderson. 1994. Geometry and development of relay ramps in normal fault systems. APPG Bulletin 78: 147-165.

Pegoraro, O. 1972. Application de la microtectonique a un étude de neotectonique. Le gol/e Maliaque (Grece centrale). These lleme cycle. USTL Montpellier.

Peña, J.L., M. Gutierrez, M.J. Ibáñez, M.V. Lozano, J. Rodríguez, M. SánchezFabre, J.L. Simón, M.A. Soriano, and L.M. Yetano. 1984. Geomorfología de la provincial de Teruel. Teruel: Instituto de Estudios Turolenses.

Platt, N., and V.P. Wright. 1991. Lacustrine carbonates: Facies models, facies distributions and hydrocarbon aspects. In Lacustrine facies analysis, International Association of Sedimentologists, special publication, ed. P. Anadón, L. Cabrera, and K. Kelts, vol. 13, 57-74.

Posamentier, H.W., and P.R. Vail. 1988. Eustatic controls on clastic deposition. II. Sequence and systems tract models. In Sea Level Changes--An Integrated Approach, ed. C.K. Wilgus, B.S. Hastings, C.G.St.C. Kendall, H. W. Posamentier, C.A. Ross, and J.C. Van Wagoner. SEPM Special Publication 42: 125-154.

Postma, G., and T.B. Roep. 1985. Resediment conglomerates in the bottomsets of Gilbert-type gravel deltas. Journal of Sedimentary Petrology 55: 874-885.

Reches, Z. 1978. Analysis of faulting in three-dimensional strain fields. Tectonophysics 47: 109-129.

Reches, Z., and J.H. Dieterich. 1983. Faulting of rocks in three-dimensional strain fields. I. Failure of rocks in polyaxial, servo-control experiments. Tectonophysics 95: 111-132.

Rodríguez-López, J.P., C.L. Liesa, J. van Dam, P. Lafuente, L.E. Arlegui, L. Ezquerro, and P.L. de Boer. 2012. Aeolian construction and alluvial dismantling of a fault-bounded intracontinental aeolian dune field (Teruel Basin, Spain): A continental perspective on late Pliocene climate change and variability. Sedimentology 59: 1536-1567.
Rotevatn, A., T.B. Kristensen, A.K. Ksienzyk, K. Wemmer, G.A. Henstra, I. Midtkandal, S.-A. Grundvåg, and A. Andresen. 2018. Structural inheritance and rapid rift-length establishment in a multiphase rift: The East Greenland rift system and its Caledonian orogenic ancestry. Tectonics 37. https://doi.org/10.1029/2018TC005018.

Salas, R., and A. Casas. 1993. Mesozoic extensional tectonics, stratigraphy and crustal evolution during the Alpine cycle of the eastern Iberian basin. Tectonophysics 228: 33-55.

Santolaria, P., M.A. Luzón, A.M. Casa, and R. Soto. 2015. Coupling far and near tectonic singnals in syn-orogenic sediments: The Olvena growth strata (sierras Marginales, southern Pyrenees). Geologica Acta 13: 297-308.

Simón, J.L. 1982. Compresión y distensión alpinas en la Cadena Ibérica oriental, PhD Thesis, 1984. Teruel: Publ. Instituto de Estudios Turolenses.

Simón, J.L. 1983. Tectónica y neotectónica del sistema de fosas de Teruel. Vol. 69, 21-97. Teruel.

Simón, J.L. 1986. Analysis of a gradual change in stress regime (example from the eastern Iberian chain, Spain). Tectonophysics 124: 37-53.

Simón, J.L. 1989. Recent stress field and fracturing in the Iberian chain and Ebro Basin. Journal of Structural Geology 11: 285-294.

Simón, J.L., L.E. Arlegui, and C.L. Liesa. 2008. Stress partitioning: A practical concept for Analysing boundary conditions of brittle deformation. Geodinamica Acta 21 (3): 107-115.

Simón, J.L., L.E. Arlegui, C.L. Liesa, and A. Maestro. 1999. Stress perturbations registered by jointing near strike-slip, normal, and reverse faults: Examples from the Ebro Basin, Spain. Journal of Geophysical Research: Solid Earth 104: 15141-15153.

Simón, J.L., F.J. Serón, and A.M. Casas. 1988. Stress deflection and fracture development in a multidirectional extension regime: Mathematical and experimental approach with field examples. Annales Tectonicae 2: 21-32.

Simón-Porcar, G., C.L. Liesa, and J.L. Simón. 2018. El ancestro mioceno del alto Alfambra: persistencia de un drenaje S-N en la depresión de El Pobo (Teruel, Cordillera Ibérica). Geogaceta 64: 111-114.

Simón-Porcar, G., J.L. Simón, and C.L. Liesa. 2019. El Neógeno de la Depresión de El Pobo (Teruel, Cordillera Ibérica): vaciado erosivos, tectónica extensional y modelo de cuenca. Submitted to Revista de la Sociedad Geológica de España.

Soria, A.R. 1997. La sedimentación en las cuencas marginales del surco ibérico durante el Cretácico Inferior y su control tectónico, Zaragoza, Unpublished Thesis Doctoral. Universidad de Zaragoza.

Soria, A.R., M.N. Meléndez, A. Meléndez, C.L. Liesa, M. Aurell, and J.C. Goméz Fernández. 2000. The early cretaceous of the Iberian Basin (northeastern Spain). In Lake basins through space and time, AAPG studies in Geology, ed. E.H. Gierlowski-Kordesch and K.R. Kelts, vol. 46, 285-294.

Tchalenko, J.S. 1970. Similarities between shear zones of different magnitudes. GSA Bulletin 81: 1625-1640.

Trudgill, B. 2002. Structural controls on drainage development in the Canyonlands grabens of Southeast Utah. AAPG Bulletin 86: 1095-1112.

Trudgill, B., and J. Cartwright. 1994. Relay-ramp formsand normal-fault linkages, Canyonlands National Park, Utah. GSA Bulletin 106: 1143-1157.

Walsh, J.J., J. Watterson, W.R. Bailey, and C. Childs. 1999. Fault relays, bends and branch-lines. Journal of Structural Geology 21: 1019-1026.

Weerd, A. 1976. Rodent faunas of the Mio-Pliocene continental sediments of the Teruel-Alfambra region, Spain. PhD Thesis. Utrecht: Utrecht Micropaleontol. Bulletin, Special Publication 2.

Willemse, E.J.M., D.D. Pollard, and A. Aydin. 1996. Three dimensional analyses of slip distributions on normal fault arrays with consequences for fault scaling. Journal of Structural Geology 18: 295-309.

Willsey, S.P., P.J. Umhoefer, and G.E. Hillay. 2002. Early evolution of an extensional monocline by a propagating normal fault: $3 \mathrm{D}$ analysis from combined field study and numerical modeling. Journal of Structural Geology 24: 651-669.

Withjack, M.O., R.W. Schlische, and P.E. Olsen. 2002. Rift-basin structure and its influence on sedimentary systems. In Sedimentation in Continental Rifts, ed. R.W. Renaut and G.M. Ashley, vol. 73, 57-81. Tulsa: SEPM Special Publication.

Wrigth, V.P. 1990. Lacustrine carbonates. In Carbonate sedimentology, ed. M.E. Tucker and V.P. Wright, 164-190. Oxford Blackwell Science Publications. 
Younes, A.l., and K.R. McClay. 2001. Role of basement fabric on rift architecture: Gulf of Suez-Red Sea, Egypt. AAPG Bulletin 86: 1003-1102.

Younes, A.I., and K.R. McClay. 2002. Development of accommodation zones in the Gulf of Suez-Red Sea rift, Egypt. AAPG Bulletin 86: 1007-1010.

\section{Publisher's Note}

Springer Nature remains neutral with regard to jurisdictional claims in published maps and institutional affiliations.

Submit your manuscript to a SpringerOpen ${ }^{\mathcal{O}}$ journal and benefit from:

- Convenient online submission

- Rigorous peer review

- Open access: articles freely available online

- High visibility within the field

- Retaining the copyright to your article

Submit your next manuscript at $\boldsymbol{\wedge}$ springeropen.com 